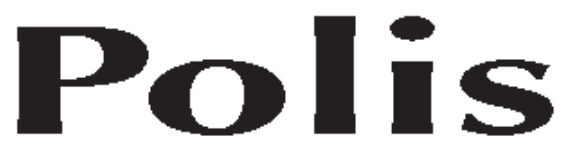

Revista de la Universidad Bolivariana

Volumen 7, No 21, 2008

\title{
El sistema global neoliberal
}

\section{Hernán Fair}

En lugar de las antiguas necesidades, satisfechas con productos nacionales, surgen necesidades nuevas, que reclaman para satisfacción productos de los países más

apartados y de los climas más diversos. En lugar del antiguo aislamiento, y de las regiones y naciones que se

bastaban a sí mismas, se establece un intercambio

universal, una interdependencia universal de las naciones. Y esto se refiere tanto a la producción material, como a la producción intelectual (...). Merced al rápido perfeccionamiento de los instrumentos de producción y al constante progreso de los medios de comunicación, la burguesía arrastra a la corriente de la civilización a todas

las naciones.

(Karl Marx y Frederick Engels, Manifiesto Comunista)

Resumen: En los últimos 30 años asistimos a un drástico proceso de cambio que ha modificado profundamente los parámetros con los que se guiaba la relación entre el Estado y la Sociedad civil. Este proceso, ligado a la hegemonización mundial del neoliberalismo, ha generado intensas transformaciones en los diversos campos. Este artículo se propone indagar en esas transformaciones. Para ello, examina las características principales que definen a este paradigma, dando cuenta de la apropiación que han hecho sus principales teóricos del concepto de globalización. En segundo término, analiza los efectos que sus políticas han provocado en la política, la economía, la cultura y la sociedad. Se sostiene que el éxito del "sistema global neoliberal" reside en que ha logrado despolitizar en gran medida a la sociedad y a su propio discurso. En este sentido, se coloca el eje en sus efectos de despolitización, en particular durante la década del noventa, fase critica del sistema. En el tramo final, se pregunta acerca de las alternativas surgidas en las nuevas democracias latinoamericanas al modelo de globalización neoliberal.

Palabras clave: Globalización, neoliberalismo, modernidad, política, hegemonía.

\section{The global neoliberal system}

Abstract: In the last 30 years we attended a dramatic process of change that has deeply modified the parameters with which the relation between the State and Civil society was guided. This process, related with the world-wide hegemony of neoliberalism, has generated deep transformations in the diverse fields. This article sets out to investigate in those transformations. For that, it examines the basic characteristics that define this paradigm, giving account of the appropriation that has been made by their main theoreticians of the globalization concept. In second term, it analyzes the effects that their policies have caused in politics, economy, culture and society. It is maintained that the success of the "Neoliberal global system" resides in in that it has managed to depoliticize to a great extent society and its own speech. In

*Universidad de Buenos Aires, Buenso Aires, Argentina Email: herfair@ hotmail.com. 
this sense, the axis is placed in its depoliticization effects, particularly during the Nineties, a critical period for the system. In the final section, it is asked about the alternatives arisen in the new Latin American democracies to the model of neoliberal globalization.

Key words: Globalization, neoliberalism, modernity, policy, hegemony.

\section{Introducción}

Desde hace unos años se debate si estamos asistiendo al fin de la modernidad ${ }^{1}$ y al comienzo de una nueva era o si este período está asumiendo características novedosas. Entre los defensores de la modernidad podemos diferenciar, siguiendo a Beck (1996), dos enfoques principales. El primero es el que habla de modernidad clásica. Se caracteriza por equiparar modernización con modernización industrial. Este enfoque tiene, asimismo, dos escuelas que rivalizan entre sí, la funcionalista y la marxista, las cuales han desarrollado, por su parte, las variantes de postindustrialismo (Bell, Touraine) y el capitalismo tardío (Offe, Habermas). Por otro lado, se agrupan, en cambio, las teorías de la postmodernidad (Lyotard). Si bien estas teorías asocian modernización con modernidad socio-industrial, lo hacen con derivaciones negativas. ${ }^{2}$

Según Scott Lash, el primero que comenzó a referirse a que la etapa moderna había

\footnotetext{
1 Por modernidad entendemos los modos de vida u organización social que surgieron en Europa, principalmente Francia e Inglaterra, entre el siglo XVI (Berman, 1988; Lash, 1997a) y comienzos del siglo XVII (Giddens, 1993), pero que ocuparon un lugar central en el siglo XVIII (Habermas, 1989), sobre todo a partir del aporte de pensadores muy diversos como Voltaire, d'Alembert, Diderot, Condorcet, Hume, Adam Smith, Saint-Simón, Auguste Comte, Jeremy Bentham y John Stuart Mill (Harvey, 1998).

${ }^{2}$ Estas teorías críticas de la modernidad tienen, a su vez, algunos antecedentes en los siglos XIX y XX, con los llamados "modernistas". Se trata de pensadores críticos de los valores de la modernidad (racionalismo, Iluminismo, ciencia objetiva), aunque se ubican paradójicamente dentro de sus mismos supuestos teóricos. Según Berman (1988: 5-25), los máximos exponentes de esta visión son Nietszche, Marx, Weber, Marcuse y Foucault. Lash (1997a), por su parte, si bien coincide en situar en esta lista a Nietszche, Weber y Foucault, incorpora a Durkheim, Simmel, Habermas y Bell, ignorando a Marx y Marcuse. En un análisis más detallado, que no ignora la contribución crucial realizada por Nietszche, Weber, Marx e incluso Mao y Lukács, Harvey hace hincapié en la fuerte "destrucción creadora" que, principalmente desde la arquitectura modernista (LeCorbusier, Lloyd Wright, Van der Rohe, Gropius), el arte (Monnet, Picasso, Proust, Joice) y la lingüística y filosofía estructuralista (Kuhn, Feyerabend, De Saussure, Barthes, Foucault), se ha efectuado a los postulados básicos de la modernidad (véase Harvey, 1998)..
} 
llegado a su fin y que, en su lugar, se estaba asistiendo a una nueva era que denominó posmoderna fue Jean Francois Lyotard. En su libro La condición postmoderna, este autor afirma que el elemento principal que determina el paso de una sociedad moderna a una postmoderna está asociado al fin del período industrial y el comienzo de una nueva era en la que predomina la información y el saber técnico ${ }^{3}$ (citado en Lash, 1997a: 20).

Anthony Giddens, en la misma línea, considera que la postmodernidad se refiere a cuestiones culturales, y no materiales, que reflexionan sobre la naturaleza de la modernidad (Giddens, 1993: 17). Por postmodernidad entiende básicamente una crítica epistemológica y filosófica que expresa que nada puede afirmarse con certeza, que la historia no "camina" hacia el progreso indefectible y que hay un aumento de las preocupaciones ecológicas y de los nuevos movimientos sociales (Ibíd.: 52). Al igual que Lash, este autor considera que el pensamiento de Lyotard debería ser incluido dentro de esta corriente postmoderna inaugurada con la crítica nietszcheana ${ }^{4}$, particularmente a partir de su tesis sobre el fin de "la gran narrativa" $"$ y su crítica a la razón Iluminista y la ciencia como ámbitos privilegiados de conocimiento. Las transformaciones económicas las considera, en cambio, siguiendo a Bell, como el paso de una sociedad centrada en la producción industrial hacia una "sociedad postindustrial" (Ibíd.: 16). Sin embargo, Giddens tampoco está de acuerdo en llamar postmodernidad a estos cambios epistemológicos iniciados con Nietzsche. ${ }^{6}$ Según él, las disyunciones que han tenido lugar deben verse, más bien, como "resultantes de la "autoclarificación" del pensamiento moderno, en tanto los restos de la cultura tradicional y de la visión providencial se disipan" (Ibíd.: 56). Este autor afirma que lo que sucede es que, dada la complejidad actual del mundo, y la imposibilidad de controlar sus fenómenos, los investigadores sociales terminan cayendo en una desorientación, y esta desorientación los

\footnotetext{
${ }^{3}$ Lyotard critica particularmente a lo que denomina el "saber científico", un tipo de saber didáctico de matriz Iluminista que legitima sus enunciados como un "valor de verdad", excluyendo al mismo tiempo los demás discursos, a quienes acusa de "atrasados", formado en opiniones, prejuicios, ignorancias o ideologías. De este modo, y frente al fracaso de los "grandes relatos" basados en el Espíritu (Hegel), la emancipación humana (Marx) y el "consenso racional" (Habermas), concluye que la ciencia se transforma en un "metadiscurso" basado en una "pretensión ontológica" (véase Lyotard, 1992). Volveremos más adelante sobre este particular. ${ }^{4}$ En efecto, el pensador alemán desarrolló a lo largo de su obra una crítica feroz al conjunto de la modernidad que incluyó el rechazo al sujeto, la razón, la ciencia, la idea de verdad y la fe en Dios.

${ }^{5}$ Se refiere con ello al desvanecimiento de la "línea de relato englobadora", los "metarrelatos", en los términos de Lyotard (1992), mediante los cuales se coloca al hombre en la historia dentro de un pasado determinado y un futuro predecible (véase Giddens, 1993: 16).

${ }^{6}$ La teoría de Nietszche opera como un intento extremo de demoler al sujeto racional y a la idea representacional de verdad del Iluminismo en pos de una teoría constructivista que promueve la primacía de los instintos y la "voluntad de poder". Sin embargo, su teoría nihilista termina defendiendo, al mismo tiempo, una moral aristocrática de carácter elitista (véanse Assoun, 1984 y Lash, 1997a).
} 
lleva a dudar de la posibilidad de la existencia de un conocimiento sistemático de la organización social. Según sostiene, actualmente no estamos entrando en la postmodernidad, sino que las consecuencias de la modernidad se están radicalizando y universalizando como nunca antes. En todo caso, afirma, estamos en presencia de un orden nuevo y diferente que es "postmoderno" (Giddens, 1993: 17).

Niklas Luhmann (1997), en la línea de Giddens, sostiene que la separación entre modernidad y posmodernidad es sólo una "diferenciación semántica", ya que no es posible diferenciar estructuralmente ambos conceptos. En todo caso, las características más relevantes de la sociedad moderna, esto es, unos medios de comunicación plenamente desarrollados y una diferenciación funcional más extendida, han llegado a tales magnitudes que son en la actualidad irreversibles (Luhmann, 1997: 41).

De manera similar, Harvey (1998) considera que resulta muy difícil discernir el momento exacto que define el paso desde la modernidad a la posmodernidad. Si bien es consciente de las profundas transformaciones acontecidas en las últimas décadas, principalmente en lo que refiere a los grandes "meta-relatos" (incluyendo el marxismo, el freudismo y todas las formas de la Razón de la Ilustración) y la preocupación creciente que adquieren los "otros mundos" y "otras voces" largamente silenciadas (mujeres, gays, negros, pueblos colonizados), señala que existe mucha confusión acerca de la coherencia o el significado que define a las nuevas ideas emergentes, no pudiéndose evaluar, interpretar y explicar si se trata de una desconstrucción, superación o evitación de los sentimientos modernistas (Harvey, 1998: 59 y ss.).

Por último, Beck (1996) y Lash (1997b), entienden también que la modernidad continúa existiendo como tal, pero que ha adquirido ribetes diferentes. Según estos autores, estamos asistiendo al fin de la "modernidad simple", ligada al industrialismo y a la ideología del "fatalismo", y el nacimiento de lo que denominan una "modernidad reflexiva", caracterizada por el renacimiento de lo político y de la contingencia de lo social. En la misma línea, Giddens (1995) considera que en la actualidad estamos en presencia de un período de transformación cuya principal característica es el traslado desde una sociedad de "riesgo externo" a una centrada en el "riesgo manufacturado".

En el siguiente trabajo partiremos de un rechazo del concepto de postmodernidad. En efecto, como sostiene la mayoría de los estos autores, creemos que no es posible establecer, pese a los cambios acontecidos en los múltiples campos durante las últimas décadas, una cuantificación y cualificación que nos permita determinar el momento exacto en el que la sociedad moderna habría dado paso a una sociedad posmoderna. Del mismo modo, la confusión retorna al querer plantear los autores y características semánticas que definirían 
estrictamente al nuevo paradigma emergente. ${ }^{7}$ En este sentido, rechazamos también el concepto de posmodernismo. En contraposición, aceptaremos la vigencia del concepto de modernidad para referirnos a las características que definen a la época actual, e incluso retomaremos en gran medida la fuerte crítica modernista de los siglos XIX y XX (Berman, 1988; Lash, 1997a; Harvey, 1998). De todos modos, entendemos que la etapa en la que vivimos actualmente debería tener un nuevo nombre. Siguiendo a la costumbre que inauguró la modernidad de identificarse a sí misma para diferenciarse de épocas pasadas (Luhmann, 1997), denominaremos a esta nueva etapa "sistema global neoliberal". Nos referimos a sistema en lugar de sociedad por entender que este último término denota integración y solidaridad (Habermas, 1989), en lugar del preferible "interrelación" y conflicto, asociado al primero. Decimos sistema global, en tanto estamos asistiendo a un incremento de la interdependencia entre los Estados y con los organismos transnacionales y multinacionales cuya intensidad no se había visto nunca antes en la historia. Este fenómeno, conocido como globalización o mundialización, aunque tiene antecedentes históricos que se remontan a los orígenes del capitalismo (Borón, 1999; Gambina, 1999; Forte, 2003), adquirirá mayor relevancia a partir de la década del '60, relacionado con los cambios tecnológicos y el crecimiento mundial de las empresas multi y transnacionales (Giddens, 1993; Harvey, 1998; Minsburg, 1999). Pero en este trabajo nos centraremos en lo que denominamos la fase "crítica" del sistema global. El inicio de esta nueva fase se sitúa a mediados de la década del '70, en coincidencia con la aplicación, en Chile (1973) y Argentina (1976), de las primeras medidas del modelo de acumulación neoliberal. Sin embargo, sostenemos que la nueva etapa sólo alcanzará una expansión hegemónica desde finales de los ochenta y, principalmente, durante los años noventa, con la caída del Muro de Berlín y el fracaso del comunismo.

Entendemos que esta nueva fase de la "globalización neoliberal" ha originado un proceso de profundas transformaciones que afectan casi a cualquier aspecto de nuestras vidas. El objetivo principal de este trabajo consiste, precisamente, en indagar en esas transformaciones. Específicamente, pretendemos analizar las consecuencias que este nuevo orden global ha tenido, durante la década pasada, en los campos de la política, la economía, la cultura y la sociedad. Al mismo tiempo, pretendemos criticar algunas de las visiones predominantes sobre este tema en el campo de la sociología. Finalmente, procuramos dar cuenta de las transformaciones generadas en los últimos años a partir de la indagación de las características que definen a los nuevos liderazgos surgidos en Latinoamérica.

\footnotetext{
${ }^{7}$ Como señala Harvey, aunque resultan evidentes las transformaciones ocurridas a partir de 1970 en diversos campos, no por ello podemos determinar el paso de la modernidad a la posmodernidad. Un ejemplo que nos muestra esta confusión lo representa la teoría nihilista de Nietszche, de finales del siglo XIX: ¿dónde deberíamos situarla, como modernista o como posmodernista? En ese contexto, el autor concluye que existe más continuidad que ruptura entre ambas corrientes y que, en todo caso, el posmodernismo expresa una especie de crisis particular del movimiento modernista (véase Harvey, 1998, especialmente p. 137). 


\section{Transformaciones de la modernidad en la fase actual}

A partir de la década del '60 del siglo pasado, la modernidad ingresó en una nueva etapa caracterizada por múltiples transformaciones. Comenzando por el campo ${ }^{8}$ político, se asiste a una disminución de las soberanías estatales, socavadas por el poder creciente que adquieren las empresas multinacionales y transnacionales y los organismos multilaterales de crédito (Giddens, 1993: 73; Harvey, 1998). Asimismo, se genera una creciente asimetría de poder entre los Estados y, desde el colapso del comunismo, un orden mundial unipolar hegemonizado política, cultural, económica y militarmente por una única superpotencia imperial. ${ }^{9}$ Al mismo tiempo, se observa una pérdida de identificación a nivel mundial con los partidos, los sindicatos y la actividad política en general. Su declive, más allá de factores internos ligados a las denuncias de corrupción estatal por parte de los medios de comunicación, como pretenden ciertos análisis "culturalistas" (Castells, 2001), está íntimamente relacionado, como luego veremos, con la pérdida de poder que sufrieron algunos sectores a partir de la década del '70 y con la eficacia del discurso neoliberal en generar resignación social e impotencia frente a las escasas posibilidades de acción en el nuevo contexto internacional.

En relación al campo cultural, Lash (1997a) sostiene que, a diferencia de la época anterior, que tenía una posición crítica frente a la mercantilización, el público de lo que llama la cultura posmodernista, formado por una nueva clase media "yuppi", mantiene una conformidad con el orden burgués, lo que se observa en el rechazo de las vanguardias estéticas y políticas. Esta nueva burguesía "yuppificada" se caracteriza por adorar el consumo de mercancías innecesarias, "superficialidad fabricada" (Harvey, 1998: 108), que actúan como símbolos de status que otorgan "distinciones de envidia" con respecto a otros grupos de menores ingresos ${ }^{10}$ (Lash, 1997a: 35-41; Harvey, 1998).

En lo que respecta a la clase obrera, Lash afirma que, si bien la cultura se masifica, se

\footnotetext{
${ }^{8}$ Preferimos hablar de campos en lugar de esferas (Weber, 1984; Lash, 1997a) o sistemas (Luhmann, 1997) ya que entendemos, con Bourdieu, que tanto la economía como los otros campos están impregnados de relaciones de fuerza y actúan en interdependencia mutua (Bourdieu, 2000a). En ese contexto, la diferenciación conceptual entre los diferentes campos no pasa de ser una cuestión meramente analítica.

${ }^{9}$ De este modo, nos diferenciamos de autores como Castells, quien señala que presenciamos en la actualidad un mundo caracterizado por la multipolaridad, la "soberanía compartida" y la formación de un "amplio consorcio de naciones", sobre todo a partir de las nuevas funciones dedicadas a la seguridad por parte de la OTAN (véase Castells, 2001: 291 y 334).

${ }^{10}$ La noción de "distinción" ha sido analizada en detalle por el sociólogo francés Pierre Bourdieu para hacer referencia al modo en el que las clases medias utilizan el consumo (ya sea de ropa de marca, automóviles equipados, tecnología moderna u otras mercancías similares) para intentar distinguirse, muchas veces inconscientemente, de las clases más bajas. Al respecto, véase Bourdieu (1984, 1999b). 
produce un descentramiento de su identidad. Este descentramiento es causado por el abandono de la cultura realista, ${ }^{11}$ cultura que había ayudado a crear una identidad social opositora al individualismo burgués, y que ahora adquiere ribetes diferentes con el surgimiento del rock, el aumento del poder adquisitivo de los jóvenes y el surgimiento de la noción de adolescencia. Estos elementos, junto con la expansión mundial del cine y la televisión, tienden a invadir de imágenes y por lo tanto, de símbolos, al anteriormente hegemónico lenguaje y, particularmente, a entremezclar los campos cultural y comercial ${ }^{12}$ (Lash, 1997a: 46). En ese contexto, se produce una fusión con lo material en diferentes ramas culturales, como la educación (por ejemplo, la recaudación de las escuelas privadas), lo audiovisual (ingresos de canales de TV y de radio, así como de videos y de cine), lo editorial (recaudación comercial de libros, revistas y diarios), el arte (como los museos privados y el patrocinio privado) y la propaganda (desde carteles públicos hasta Internet) (Lash, 1997a: 67; Harvey, 1998: 77-83 y ss.), lo que ha llevado a algunos autores a señalar su efecto de indiferenciación y, por tanto, de naturalización del nuevo orden de mercado emergente (Jameson, 2003: 325).

Esta tendencia a fusionar la cultura con el campo material, que Lash (1997a) denomina, siguiendo a Bourdieu, como la presencia de una "economía cultural" se expresa, por otra parte, en el traspaso de un régimen de producción planificada y a gran escala, definido por el modelo laboral fordista-taylorista de producción serial, tal como caracterizaba a la producción industrial de los famosos Ford "T", a un tipo de producción flexible y racionalizada, tal como caracteriza al nuevo modelo de toyotismo y "just in time" (justo a tiempo). En simultáneo, las nuevas formas de producción flexibles generan una transformación que modifica los parámetros de consumo masivo y universalizado que caracterizaban a la etapa fordista, que son reemplazadas ahora por un nuevo régimen de consumo especializado y diferencial. En efecto, si en el régimen fordista el consumo se masificaba hacia los trabajadores asalariados con el fin de incentivar una mayor demanda agregada que, desde los postulados keynesianos, dinamizara a la producción en un "círculo virtuoso" de producción, demanda, consumo y más producción, en las nuevas circunstancias de globalización de los mercados, el consumo, del mismo modo que el urbanismo, se especializa y pluraliza en la creación de mercancías adaptadas a los requerimientos puntuales de los consumidores, e incluso, a la creación de nuevas

\footnotetext{
${ }^{11}$ La visión realista se expresa en el arte y en la epistemología. En el arte considera que las entidades deben representar a los objetos sin simbolismos, mientras que en la epistemología cree en una representación fiel del objeto por parte del sujeto. No obstante, a partir de la fase moderna emparentada con el modernismo, y la incorporación de los estudios biológicos, económicos y lingüísticos así como las transformaciones en la visión representacional y unificada de la arquitectura modernista iniciada en París a mediados del siglo XIX, la idea acerca de una supuesta realidad única, verdadera y universal comienza a ser fuertemente cuestionada (véanse Lash, 1997a; Harvey, 1998).

${ }^{12}$ En este sentido es como se pueden entender el auge de las canciones en los celulares (ring tones), las remeras con imágenes de músicos, la imitación de determinados cortes de pelo, los video-clips musicales y las propagandas y programas de televisión con canciones de fondo.
} 
mercancías ornamentales que son ofertadas como necesarias, aunque fragmentadas y segmentadas de acuerdo al sector económico y social al que se dirigen (Harvey, 1998).

En el campo económico, finalmente, lo que definimos como el "sistema global neoliberal" 13 está asociado a la presencia de un drástico proceso de cambio en el modo de producción que caracterizaba al modelo fordista-keynesiano, que como vimos, estaba centrado en la industrialización y el consumo masivo, el cual es reemplazado ahora por un nuevo régimen o patrón de acumulación vinculado a reformas estructurales de mercado de orientación neoliberal (García Delgado, 1994, 1998; Harvey, 1998). Este cambio fundamental en los mecanismos de acumulación y desarrollo del sistema se verifica en el desplazamiento desde un capitalismo "estadocéntrico" o "capitalismo organizado" (Lash, 1997b: 61), donde el Estado era el principal actor a partir de su función crucial en la asignación y regulación de un conjunto de bienes y servicios públicos universales, a una nueva matriz de acumulación "mercadocéntrica" (Cavarozzi, 1997), en el cual el mercado y la actividad privada pasa a ocupar esa función (Borón, 2000), pero también, como luego veremos con más detenimiento, en la generación de nuevos mecanismos políticoideológicos de dominación que trascienden el análisis reduccionista centrado en la dimensión puramente economicista de mercado (Harvey, 1998: 143-145 y ss.).

Como señala Giddens (1993), en esta nueva etapa se radicalizan, además, las "discontinuidades" que caracterizan a la modernidad. Por un lado, el "ámbito de cambio" se amplía hasta generar una interdependencia comercial y financiera entre los Estados cada vez mayor. En efecto, con el surgimiento de los cables transatlánticos y transpacíficos en los años '60 (Giddens, 1993: 20) y los procesos de liberalización comercial y sobre todo

\footnotetext{
${ }^{13}$ El término "sistema global neoliberal" encuentra antecedentes en la noción de "sistema mundo" del teórico marxista Imannuel Wallerstein. Este tipo de enfoque buscaba analizar la formación y la evolución del modo capitalista de producción como un sistema de relaciones económico-sociales, políticas y culturales que tiene su origen a finales de la Edad Media europea y que evoluciona en dirección a convertirse en un sistema planetario y confundirse con la economía mundial. Destaca, en este sentido, la existencia de un centro, una periferia y una semi-periferia, además de distinguir, entre las economías centrales, una economía hegemónica que articula al conjunto del sistema (véase Wallerstein, 1979). Debemos señalar que este enfoque del "sistema mundial" halla como antecedente inmediato la teoría del "imperialismo" de Lenin y, anteriormente, la noción acerca del capitalismo y su expansión globalizadora desde el descubrimiento de América planteada en su momento por Marx y Engels en el Manifiesto Comunista (véanse Borón, 1999; Gambina, 1999; Minsburg, 1999; Forte, 2003). Más recientemente, ha sido retomado por la denominada "Teoría de la dependencia", que indaga en las diversas formas de dominación del capital en contextos de transnacionalización de los mercados. Sobre esta teoría, véanse Cardoso y Faletto (1976) y Lechner (1977).
} 
financiera, iniciados tras la crisis del petróleo de $1973,{ }^{14}$ los capitales dejan de estar inmovilizados en las fábricas y en los mercados locales de trabajo, como ocurría anteriormente, y fluyen de un lado al otro del planeta de manera constante y veloz en busca de una mayor tasa de ganancias (Harvey, 1998: 184 y ss.). El resultado de ello es un incremento de la separación espacio-temporal, potenciado por la importancia creciente que adquieren las diferentes formas en las que se representa el dinero. ${ }^{15}$ Por el otro, el "ritmo de cambio" se ve fuertemente incrementado como consecuencia de la revolución y diversificación en el transporte y las telecomunicaciones, lo que se expresa en la extensión mundial de la televisión, el video, la digitación, el grabador y, en particular, el enlace de todos los medios en un intertexto digital interactivo, producido por la red Internet $^{16}$ (Giddens, 1993; Castells, 2001: 283-288).

Estas transformaciones, extendidas durante la década del '80, adquirieron una proyección mundial definitiva desde comienzos de los años '90, relacionados con el colosal desarrollo de las corporaciones transnacionales, ${ }^{17}$ la expansión del capital financiero y especulativo $^{18}$ y el colapso del comunismo (Harvey, 1998; Minsburg, 1999). El resultado de ello será la presencia de un fenómeno conocido comúnmente como globalización o mundialización, que se caracteriza por la "intensificación de las relaciones sociales en todo el mundo por las que se enlazan lugares lejanos, de manera tal que los acontecimientos locales están configurados por acontecimientos que ocurren a muchos kilómetros de distancia o viceversa" (Giddens, 1993: 67-68). Este fenómeno, sin embargo, no habría podido ser posible sin la fusión que estableció este proceso con el neoliberalismo. A continuación, analizaremos el modo como se construyó esa ligazón y las características que asumió la globalización durante la fase crítica de expansión mundial de este modelo.

\footnotetext{
${ }^{14}$ Los cambios de origen tecnológico y económico, aunque con antecedentes a finales de los años ‘60, tienen como punto de referencia la crisis del dólar de 1971 y la del petróleo de 1973. Esta última volvió prioritario utilizar materiales sintéticos para reemplazar a las materias primas estratégicas y buscar formas de producción que insumieran menos energía. El nuevo paradigma tecnológico se conformó en torno a la microelectrónica y posibilitó el abaratamiento de la información. El resultado fue que las nuevas formas de producción requerían más información y menos contenido de energía, materiales y mano de obra (véanse García Delgado, 1998: 25; Harvey, 1998).

${ }^{15}$ En efecto, un individuo puede emitir un cheque un día y que el receptor lo cobre varios días después de emitido o puede pedir un crédito al banco y pagarlo meses más tarde. En la era premoderna, en cambio, la transacción era instantánea (Giddens, 1993).

${ }^{16}$ Le costó 50 años a la radio conseguir una audiencia de 50 millones en Estados Unidos. La misma cantidad de gente tardó sólo 15 años con los ordenadores y 4 con Internet (Giddens, 2000: 24).

${ }^{17}$ Las inversiones extranjeras directas de las corporaciones transnacionales casi se cuadriplicaron desde los 756,7 mil millones de dólares en 1985 a los 2732,6 mil millones de dólares en 1995 (Minsburg, 1999: 21).

${ }^{18}$ En particular, a partir de la expansión de las tasas de interés nacionales y la desregulación financiera llevadas a cabo en los países latinoamericanos para atraer capitales externos y obtener préstamos financieros. Sobre el caso argentino, uno de los más extremos de la región, véase particularmente Basualdo (2006).
} 


\section{El sistema global neoliberal}

El neoliberalismo es un modelo económico surgido en la posguerra como una reacción teórica y política contra el Estado de Bienestar (Anderson, 1997; Ezcurra, 1998: 35). Creado por el economista austríaco Friedrich Von Hayek en 1944 y desarrollado con amplitud desde 1947, a partir de los aportes del monetarista estadounidense Milton Friedman, comenzó a implementarse en 1973, durante el régimen dictatorial del General chileno Augusto Pinochet y en 1976, durante la dictadura militar argentina. ${ }^{19}$ Unos años más tarde, fue instaurado por Margaret Thatcher en Gran Bretaña (1979) y Ronald Reagan en Estados Unidos (1980). Luego de propagarse por el resto de Europa y toda Latinoamérica desde finales de la década del '80, a comienzos de la década siguiente se expandiría a los ex países comunistas, adquiriendo una hegemonía a nivel planetaria (Anderson, 1997).

Para entender esta hegemonización debemos tener en cuenta que, a comienzos de la década del '80, los gobiernos neoconservadores de Reagan y Thatcher llevaron a cabo una "reorganización ideológica" en los sectores neoliberales que resultaría clave. Si anteriormente estos sectores habían apoyado a gobiernos dictatoriales, como en el caso del General Augusto Pinochet en Chile y la Junta Militar en Argentina, para evitar el "peligro rojo" y la "subversión marxista", su punto de partida actual consistía en conciliar los principios neoliberales con los valores democráticos. Según la nueva concepción, no podría haber democracia sin capitalismo, ya que los dos eran considerados intrínsecamente inseparables $^{20}$ (Ezcurra, 1998: 44-47).

\footnotetext{
${ }^{19}$ Esto no impidió, sin embargo, que no lo hiciera sin contradicciones. En efecto, a pesar del discurso ortodoxo de la dictadura militar argentina, el veto militar al desempleo y las contradicciones internas en las Fuerzas Armadas y en los grupos de poder empresarial (principalmente por parte de los sectores contratistas y proveedores del Estado), impidieron que se llevaran a cabo las privatizaciones de las empresas estatales más allá de ciertas privatizaciones periféricas y que se reduzca el gasto público estatal. Por otra parte, el proceso de apertura comercial se realizó de manera selectiva, protegiéndose algunas grandes industrias con distintos niveles arancelarios, al tiempo que se liberalizaba completamente a las pequeñas y medianas empresas del sector (Canelo, 2004 y Castellani, 2004). El caso chileno es otro ejemplo de liberalización parcial, ya que, al igual que México y Venezuela con el petróleo, el proceso de apertura al capital transnacional no impidió que las ganancias derivadas de la industria del cobre quedaran en manos del Estado (Torre 1998). Pero además, en las décadas del ' 80 y '90 el Estado intervino fuertemente en la economía, expandiendo ampliamente el gasto social en educación y salud así como las remuneraciones, las asignaciones familiares y el ingreso mínimo (Ffrench Davis, 2004: 233). Por último, a diferencia de algunos países de la región, como por ejemplo Argentina, en Chile se establecieron controles al ingreso de capitales "golondrinas", lo que produjo menos desequilibrios en la economía y permitió evitar los efectos de la Crisis del Tequila (Ffrench Davis, 2004: 262). Por último, en este país el Estado y el mercado se complementaron en áreas como pesca, fruticultura e industria forestal, lo que le permitió mejorar su inserción económica externa (Torre, 1997, 1998).

${ }^{20}$ Este cambio de visión fue originado tras el triunfo antisomocista en Nicaragua. A partir de ese momento se comenzó a considerar que los autoritarismos deslegitimaban a los gobiernos y el respaldo popular y beneficiaban a la "subversión", que podía construir amplias coaliciones en torno a reivindicaciones democráticas. De allí se derivó que las dictaduras constituían un "boomerang" (véase Ezcurra, 1998: 46-47).
} 
La valorización de los principios democráticos fue acompañada, al mismo tiempo, por una "firme voluntad internacionalista que impulsó deliberadamente la expansión mundial del proyecto de capitalismo democrático en clave neoliberal" (Ibíd.: 45). El resultado fue el esparcimiento del modelo en los países de Latinoamérica y en los ex países comunistas del este hacia finales de la década del '80 y comienzos de los '90 (Torre, 1997, 1998; Murillo, 2005).

En segundo término, la expansión mundial de la globalización neoliberal fue posible debido a que la crisis de la deuda externa, iniciada a comienzos de los '80, obligó a los países latinoamericanos a pedir préstamos a los organismos internacionales de crédito. ${ }^{21}$ Los técnicos que formaban parte de esos organismos, principalmente el Fondo Monetario Internacional (FMI) y el Banco Mundial (BM), comenzaron a exigir la implementación de férreas políticas de estabilización macroeconómica, en especial en materia de presiones inflacionarias y de las cuentas fiscales y externas, y la realización de reformas estructurales de mercado, como una forma de cobrar los préstamos externos adeudados a los países de América Latina (Harvey, 1998; Basualdo, 2006).

Estos ajustes y reformas estructurales, fuertemente alentados, como dijimos, por los sectores neoconservadores, apuntaban a una "profunda reorganización del Estado y la sociedad orientada por la libre operación de los mercados. Sus objetivos eran la destrucción drástica del Estado, a través de políticas de privatización de empresas estatales, la desregulación de los mercados internos, la apertura radical de las economías al capital transnacional y la contracción del gasto público social"22 (Ezcurra, 1998: 42).

En ese contexto, los teóricos del neoliberalismo comenzaron a referirse a la existencia de un proceso inevitable que sería denominado corrientemente como globalización. Este fenómeno, que, como dijimos, se iniciará en la década del ' 60 y se verá consolidado a nivel planetario a partir del colapso del comunismo, en $1991{ }^{23}$ exigía el cumplimiento de determinadas "reglas" para formar parte del mismo. De esa tarea se ocuparon los técnicos de los organismos multilaterales, los bancos acreedores y las grandes potencias mundiales

\footnotetext{
${ }^{21}$ Muchos de estos países se habían endeudado a partir de la década del '70, situación producida por el fácil acceso a los créditos blandos que inundaron el mercado interno de la mano de los llamados "petrodólares".

${ }^{22}$ Para un análisis de las características ideológicas del neoliberalismo, véanse Anderson (1997); Ezcurra (1998); Gómez (2003).

${ }^{23}$ Según Giddens (2000: 27), el control ideológico y cultural que ejercía el comunismo soviético no podía competir con la economía electrónica mundial. En este sentido, tanto la radio como la televisión jugaron un papel fundamental ya que, al mostrar las imágenes de protestas en otras regiones, incentivaron las protestas locales. 
(el Grupo de los 8) ${ }^{24}$, quienes afirmaban que si los países menos desarrollados aplicaban sus "recetas", esto es, si llevaban a cabo la privatización de las empresas estatales, la desregulación total de los mercados, la reducción y focalización del gasto público social, el equilibrio de las cuentas fiscales y la flexibilización del mercado laboral, ${ }^{25}$ lograrían la llegada masiva de inversiones externas. Esto permitiría a sus países "insertarse en el mundo", obtener el crecimiento de sus economías y generar, mediante una "mano invisible", el "derrame" que garantizara el "desarrollo sustentable" que se distribuiría espontáneamente a todos los habitantes del planeta.

Esta imposición de "recetas", metáfora que por otra parte denota "sanación" frente a lo que definían como el "cáncer" del "populismo estatista", principal culpable de la burocratización, la corrupción y la ineficiencia de las empresas públicas ${ }^{26}$ fue acompañada, además, por un discurso que aseguraba que la única respuesta posible ante la globalización era la sumisión pasiva como si se estuviera en presencia de un fenómeno inevitable como son las catástrofes naturales (Coraggio, 1999; Aronskind, 2001; Pucciarelli, 2002). Si se respetaba a las "fuerzas del mercado", esta visión fundamentalista prometía que el crecimiento de la economía mundial sería más rápido y estable, y que los frutos del desarrollo se distribuirán entre todos los habitantes del planeta (Borón, 1999; Bauman, 2003). Como veremos a continuación, esta visión de la globalización neoliberal produjo importantes consecuencias políticas, económicas, culturales y sociales.

\section{Efectos de la aplicación del sistema global neoliberal}

La aplicación del sistema global neoliberal generó profundas transformaciones en los campos político, económico, social y cultural. Para entender estas mutaciones debemos tener en cuenta, en primer lugar, el pronunciado cambio experimentado en el mapa sociopolítico y económico que se llevó a cabo a partir de la década del '70 y principios de los '80. En efecto, desde 1945 hasta 1973, el patrón de acumulación fordista-keynesiano había significado una expansión política, económica y social de los trabajadores, especialmente las pertenecientes a las industrias nacionales, lo que había permitido una

\footnotetext{
${ }^{24}$ El Grupo de los 8 o G-8 está conformado por los ocho países más industrializados del planeta: Italia, Gran Bretaña, Francia, Alemania, Estados Unidos, Canadá, Japón y Rusia (incorporado en 1998).

${ }^{25}$ Estas políticas económicas unificadoras tomarían el nombre, a partir del informe de Paul Williamson, de 1990, de "Consenso de Washington".

${ }^{26} \mathrm{Al}$ respecto, véanse las feroces críticas a la intervención del "populismo estatista" por parte de Dornsbusch y Edwards (1990) y Llach (1997). Sobre la utilización abusiva del concepto de populismo, remito al lector interesado al trabajo de Ernesto Laclau (2005a). Para una visión alternativa que critica los principales postulados de este "Pensamiento único" y sus efectos sobre las "restricciones al desarrollo", véase Castellani (2002).
} 
fuerte homogeneización, y por lo tanto un fuerte poder político, del sector sindical (García Delgado, 1994, 1998; Harvey, 1998). No obstante, con la crisis del modelo keynesiano, en consonancia con la creciente expansión mundial de las corporaciones transnacionales, se hacía necesario terminar o al menos limitar aquel poder "excesivo" del sector trabajo.

En ese contexto, a partir de la experiencia inicial en Chile (1973) y luego en Argentina (1976), comenzó a aplicarse un nuevo régimen de acumulación que redefinió drásticamente las relaciones entre el Estado y la Sociedad civil. Esta descomunal redefinición de poder, causada por la liberalización económica y las políticas de flexibilización laboral, se tradujo en posiciones de liderazgo alcanzadas por tres actores, los cuales hicieron valer no sólo sus intereses, sino también sus cosmovisiones generales. Esos actores fueron los líderes políticos pro-reformas, los grupos empresariales vinculados a este tipo de políticas y los organismos multilaterales de crédito (Repetto, 1999: 150). A estos sectores debemos agregar el inmenso poder político y económico, y la influencia que esto significaba, de los gobiernos neoconservadores de Reagan y Thatcher, los más importantes países que defendían e intentaban expandir el modelo neoliberal, y el poder y prestigio académico de los think thanks, comunicadores sociales, publicistas y economistas dedicados a la propagandización y hegemonización de las ideas neoclásicas (Borón, 2000: 122). Estos sectores, constituidos por un pequeño número de grandes empresas (las megacorporaciones transnacionales) y grandes países industrializados (el G-8), se vieron enriquecidos en desmedro de una pauperización creciente de la mayoría de los países y la inmensa mayoría de las personas. ${ }^{27}$ En efecto, al tiempo que se beneficiaba a los sectores de mayor poder político y económico, especialmente las megacorporaciones de los Estados Unidos y de las principales potencias europeas, cuyos Estados protegían firmemente a sus mercados mediante diversos tipos de regulaciones (Harvey, 1998), el nuevo orden global debilitaba fuertemente a los sectores ligados a las industrias nacionales y a los sindicatos, principalmente a los obreros y, particularmente, a los obreros de los países del llamado Tercer Mundo. En estos países, el incentivo a la privatización compulsiva de las empresas públicas, la flexibilización del empleo, la desregulación económica y la apertura irrestricta al capital transnacional de los productos fabricados en el Primer Mundo, generó un fuerte

\footnotetext{
${ }^{27}$ Como pruebas de estas transformaciones basta decir que los ingresos combinados de las 500 corporaciones más importantes de la economía mundial alcanzaron en 1994 la suma de 10.245,3 millones de dólares, lo que equivale a diez veces el PBI de toda América Latina y el Caribe en 1990 (datos citados en Borón, 2000: 119) . Además, según una comparación internacional del Programa de las Naciones Unidas para el Desarrollo (PNUD), en 1960 el 20\% más rico de la población mundial percibía un ingreso 30 veces superior al 20\% más pobre. En 1990, en cambio, las diferencias de ingresos se habían casi duplicado, siendo 59 veces mayor que el ingreso del $20 \%$ más pobre. Para 1997, la ratio era nada menos que de 74 a 1 (Ibíd., p. 112).
} 
proceso de desindustrialización, acompañado por una reducción numérica, fragmentación y segmentación de la clase obrera (Bourdieu, 1999a: 136-145; Svampa, 2005). Mientras que por un lado, estas políticas se tradujeron en un incremento descomunal del desempleo, la precarización laboral, la desigualdad social y la pobreza (Minsburg, 1999; Borón, 2000; Sader, 2001), por el otro, se tradujeron en una pérdida de la identificación previa entre un "nosotros" y un "ellos" por parte de los trabajadores (Lash, 1997a: 47-48; Bourdieu, 1999a: 46-52). Al mismo tiempo, esta pérdida de "solidaridad orgánica", ocasionó un declive del poder político de los asalariados, principalmente en el ámbito sindical (Harvey, 1998). En efecto, la fragmentación y segmentación social producida por las políticas de flexibilización y desindustrialización, junto con la creciente desocupación generada por la privatización de la mayoría de las empresas públicas, debilitaron al anteriormente homogéneo y unificado sector sindical (Tenti Fanfani, 1993; Murillo, 2005). En ese contexto, al tiempo que los sectores empresariales se homogeneizaban de manera creciente, los sectores populares y trabajadores en general se heterogeneizaban, y por lo tanto debilitaban, cada vez más ${ }^{28}$ (Villarreal, 1996).

Aunque en las nuevas circunstancias de fragmentación social han surgido otras identidades más localizadas que fomentaron un mayor pluralismo en los sectores izquierdistas hacia minorías raciales, étnicas, de género y sexuales, y con ella, nuevas formas de ciudadanía basadas en la "autorepresentación", como es el caso de la importancia que adquiere el capital social y el "Tercer Sector" (ONG's, etc.), la lucha por los Derechos Humanos o contra el abuso policial, las protestas ecológicas y los grupos feministas ${ }^{29}$ (Castells, 2001; Laclau, 2005a), estas nuevas formas de reclamo con independencia de las instituciones representativas tradicionales, que incluyen además la participación en protestas electrónicas y vecinales, terminan por limitar el poder político de los trabajadores. En efecto, lejos de ser expresión de una mayor autonomía ciudadana y un mayor grado de "autorreflexión" (Giddens, 1996) de la sociedad civil, contribuyendo a generar novedosos y promisorios lazos sociales, tal como lo entienden algunos autores (Castells, 2001: 388 y ss.; Cheresky, 2006; Quiroga, 2006: 128), las nuevas formas de protestas “light", ajenas a las

\footnotetext{
28 Estos creciente heterogeneidad y debilitamiento del poder sindical y popular se observa en el desplazamiento del trabajo regular y a tiempo completo que caracterizaba al modelo benefactor, por contratos o subcontratos de trabajo flexibles que se caracterizan por ser temporarios o de medio tiempo. Además, se observa en el fuerte incremento del cuentapropismo y del trabajo autónomo en general, en desmedro del trabajo industrial que dominaba en el modelo anterior. Así, en el 2002, el 79\% de los jóvenes de 15 a 29 años del 20\% más pobre de la población de América Latina trabajaban como cuentapropistas, empleados ambulantes y empleados domésticos (datos citados en Clarín, 11/07/07). Para un análisis más general de este proceso de flexibilización del empleo y sus efectos sobre el poder sindical, véase Harvey (1998, especialmente pp. 170-182).

${ }_{29}$ Algunos ejemplos que podemos citar son Amnistía Internacional, Médicos sin Fronteras, Oxfam (humanitarios), Greenpeace, el Grupo de los Diez de Estados Unidos, Earth First y Die Grunen (ecologistas), Manifiesto de las Lesbianas Radicales, South-hall Black Sister, Fundación Despertar, Entre Nosotras (feminismo cultural, lésbico, étnico, esencialista). Al respecto, véase Castells (2001: 135-284 y 297).
} 
demandas sociales más relevantes, y sobre todo, fragmentadas por múltiples y heterogéneos intereses divergentes, ${ }^{30}$ terminaron generando un declive del poder político de los trabajadores que terminaría por despolitizarlos (García Delgado, 1994). Esta despolitización, sin embargo, no sólo afectará a los trabajadores en general y a los sectores populares en particular, sino que incluirá también a gran parte de la sociedad, expresándose en un notorio declive a nivel planetario en el apoyo a los partidos, sindicatos y a la actividad política en general. ${ }^{31}$

Para entender esta creciente despolitización social, que algunos autores centran de manera reduccionista en la corrupción política y las denuncias por parte de los medios de comunicación que potencian el desprestigio de los dirigentes políticos (Castells, 2001: 332, 372 y ss.), debemos destacar que los teóricos de la globalización neoliberal promovieron durante los últimos años lo que se ha dado en llamar una "sociedad de consumo" basada en "sobrecargas de la demanda" (Lash, 1997a: 64). A diferencia de la cultura moderna, que consumía bienes entendidos como valores de uso, la cultura de la fase actual de la modernidad consume bienes entendidos como "valores de signos". Esto significa que los consumidores, término que reemplaza al de ciudadanos, demandan una cada vez mayor cantidad de productos, no porque los necesiten, sino, tal como to ha analizado Bourdieu (1999b), como un signo de "distinción" que provoque envidia en los demás (Lash, 1997a: 64). De esta manera se constituye una lógica que podríamos denominar "consumir y seguir consumiendo".

Este "imperialismo del gusto" (Harvey, 1998), incentivado por la superpotencia mundial y las grandes empresas multinacionales, lleva a considerar al mundo como un depósito de potenciales objetos de consumo; siguiendo los preceptos de la denominada "sociedad de consumo", alienta la búsqueda de satisfacciones; y siguiendo sus principios, induce a los individuos a creer que dar satisfacción a sus deseos es la regla que debe orientar sus elecciones y el criterio regente de una vida válida y exitosa (Bauman, 2003: 85). De este modo, y pese a que se suele hablar de una mayor libertad, en especial a partir

\footnotetext{
${ }^{30}$ Esta fragmentación social no impedirá que emerjan algunos sectores críticos de los efectos económicos y sociales de la globalización neoliberal, como los zapatistas en México, surgidos en enero de 1994 como consecuencia de la firma del tratado de Libre Comercio (Castells, 2001: 95-133), los piqueteros en Argentina, surgidos en 1996 como respuesta a las políticas de privatización de las empresas públicas (Svampa, 2005) y los grupos "globalifóbicos", surgidos en Francia y extendidos en la ciudad estadounidense de Seattle en 1999 como respuesta a los efectos de la globalización. Sin embargo, ninguno de ellos logrará constituir una contrahegemonía consistente y unificada que pudiera poner en cuestión al orden global dominante. Hemos trabajado este tema en relación al caso del movimiento de piqueteros en Argentina en Fair (2008a).

${ }^{31}$ Varias encuestas revelan el fuerte disconformismo con las instituciones y con la propia actividad política en amplios sectores de la población. Así, una encuesta realizada por Gallup y la BBC entre 50.000 personas de 68 países, devela que, a escala mundial, sólo el 13\% de la gente confía en los políticos. Ese porcentaje cae a un mínimo de $4 \%$ en América Latina (Clarín, 17/09/05). Sobre la crisis de la política en América Latina, véase particularmente Roberts (2002). Para un análisis más general, véase García Delgado (1994, 1998).
} 
del fracaso del modelo de Estado "autoritario" del keynesianismo (Castells, 2001), no existe posibilidad de elegir. Por el contrario, las conductas que promueve el código son conductas que los individuos se ven "obligados" a adoptar. Sin embargo, Bauman observa que esta visión de ausencia de alternativas, lejos de verse como tiránica, "subyace tras una sensación de seguridad y cotidianeidad que resulta, en general, gratificante". De esta manera, se constituye en la defensa más confiable de la sociedad de consumo ${ }^{32}$ (Bauman, 2003: 197).

Como señala Borón, la consecuencia de esta imposición o adopción consentida de valores, estilos culturales, íconos e imágenes proyectadas a través del mundo por el poder hegemónico estadounidense y el bombardeo propagandístico de las megacorporaciones, es la instauración de una uniformización cultural de las sociedades (Borón, 1999: 225). Esta homogeneización cultural, que algunos llaman "McDonalización" (Ritzer, 1996), constituye, a su vez, un elemento crucial como factor de "recursividad", esto es, de reproducción de las condiciones que hacen posible su existencia (Giddens, 1995: 40). Ello se debe a que, al producir, es decir, al incorporarse los "hábitus" 33 de consumo que se ofrecen, se lleva a cabo un "proceso de estructuración" que, a pesar de ser una "consecuencia no intencional" de la acción (Giddens, 1987, 1995: 43), reproduce las asimetrías estructurales de poder y, al mismo tiempo, legitima el propio sistema de dominación (Giddens, 1995: 61; Bourdieu, 2000b). En efecto, el incentivo a la competitividad y el "sálvese quien pueda" y el auge del consumo de bienes materiales exigido por el mercado para "pertenecer", al tiempo que favorece la reproducción material del capital más concentrado, fomenta la plena vigencia de un individualismo de carácter hedonista que promueve la apatía hacia la política y el refugio en el "privatismo"34 (García Delgado, 1994; Lipovetsky, 2000). De esta forma, se incentiva un "modo de regulación" apolítico que resulta plenamente funcional a la acumulación capitalista (Harvey, 1998), "facilitando la tarea de todos los poderes para infundir disciplina y obediencia a sus mandatos" 35 (Bauman, 2003: 88).

\footnotetext{
${ }^{32}$ Una excelente crítica desde la perspectiva psicoanalítica a las características que definen a la "sociedad de consumo" puede hallarse en Lebrun (2003).

${ }^{33}$ El "hábitus" ha sido definido por Bourdieu como un "sistema de disposiciones adquiridas por medio del aprendizaje implícito o explícito que (...) genera estrategias que pueden estar objetivamente conformes con los intereses objetivos de sus autores sin haber sido concebidas expresamente con este fin" (véase Bourdieu, 2000b: 125).

${ }^{34}$ Habermas (1995) acuño este concepto para dar cuenta de la despolitización generada como consecuencia de la importancia creciente que adquiere la lógica consumista (véase especialmente p. 96).

${ }^{35}$ Por disciplina entendemos, con Weber, la "obediencia habitual por parte de las masas sin resistencia ni crítica" (véase Weber, 1984: 43). Este disciplinamiento, extendido en toda la región latinoamericana durante los últimos años, ha sido particularmente importante en el caso argentino durante la década de los '90, con el auge de los créditos baratos para el consumo de automóviles, viviendas y electrodomésticos, la posibilidad de viajar al exterior para hacer turismo y la incorporación de tecnología del Primer Mundo a precios módicos. Al respecto, véase Svampa (2005).
} 
El inmovilismo social generado por el consumismo hedonista se ve acompañado, además, por tres estrategias discursivas que consideramos claves. ${ }^{36}$ En primer lugar, la vigencia de un "Pensamiento Único" que considera que "no hay alternativas" al orden vigente. En efecto, durante la década del '90, y más aún tras el estrepitoso fracaso del comunismo, se decía que este no era sólo el mejor de los mundos posibles, sino que era el único que hay. De ahí, la famosa frase de Francis Fukuyama de que habíamos llegado al "Fin de la Historia". Esto significaba que como se habían agotado las interpretaciones alternativas a la "democracia liberal", se habría terminado con la lucha política-ideológica.

Para justificar estos postulados del "imposibilismo" (Pucciarelli, 2002) los teóricos del neoliberalismo contaban con la legitimidad "neutral" garantizada por los tecnócratas del saber científico. Estos "saberes expertos" (Giddens, 1996), basados en un supuesto conocimiento superior y objetivo garantizado por la "neutralidad" de sus enunciados lógico-matemáticos (Bourdieu, 1984, 1999), contribuirán a la lisa y llana reproducción del orden dominante a partir del borramiento implícito de los intereses políticos subyacentes. ${ }^{37}$ En efecto, su lógica cientificista carente de un referente fundante que pudiera poner en evidencia su enunciación subjetiva fomentará la experiencia de un mundo sin una alteridad política con quien antagonizar, un mundo en el que, por lo tanto, ya no existirían más las relaciones de poder ni de antagonismo social entre los hombres (Lebrun, 2003; De Santos, 2006). De esta manera, lejos de "enseñar racionalidad financiera a los pueblos del mundo, como única base sólida para construir una nueva sociedad" (Castells, 2001: 298), como pretende cierta visión ingenua y netamente funcional al sistema, el discurso supuestamente apolítico de los técnicos "expertos" operaba como una nueva y eficaz forma de despolitización social que ocultaba al mismo tiempo su fuente.

En segundo término, debemos destacar la visión predominante del orden global que era definido desde los sectores dominantes como una "aldea global", en donde no existirían asimetrías de poder ni antagonismos sociales entre los Estados. En efecto, tras la caída del comunismo, y con él, de la división mundial bipolar característica de la Guerra Fría, los teóricos del neoliberalismo comenzaron a referirse a la presencia de un nuevo orden mundial, definido corrientemente como "comunidad internacional", "sociedad planetaria" o "aldea global", en el que las relaciones de poder y dominación entre los Estados parecían disolverse para siempre (Borón, 1999; Aronskind, 2001). En ese contexto, que durante la

\footnotetext{
36 Algunas de las cuestiones que analizaremos a continuación han sido desarrolladas a partir del caso argentino en Fair (2008b, 2008c).

${ }^{37}$ En efecto, lejos de ser entes neutrales que aplican de manera gestionaría su "saber superior", el discurso tecnocrático oculta las relaciones de poder que lo guían. En este sentido, podemos decir, con Verón que el discurso tecnocrático "juega al juego de la política cuando parece que está jugando a otro juego" (Verón, 1985, op. cit. 3). Sobre las características y efectos principales del discurso de la ciencia, véanse Lyotard (1992), Markoff y Montecinos (1994) y Lebrun (2003), entre otros. 
etapa anterior parecía ir "Camino a la servidumbre", para parafrasear a Friedrich Von Hayek, el mundo se encaminaba ahora de manera "inexorable" hacia un orden global interconectado y solidario que guiaría inevitablemente hacia la modernización y la felicidad para todos los pueblos del planeta. ${ }^{38}$ Es decir que, lejos de plantearse posibles efectos negativos de la aplicación de estas políticas de orientación neoliberal sobre la estructura de las economías y sociedades existentes, y sobre todo, ocultando la presencia de luchas de poder e intereses políticos que pudieran guiarlos, los defensores de este modelo de globalización neoliberal apelaban a metáforas despolitizadas que denotaban integración social y ausencia de conflictos y antagonismos sociales. ${ }^{39}$ El resultado de este discurso eficaz, potenciado por la modernización tecnológica que define a la nueva etapa de acumulación (García Delgado, 1994) y la idea de interconexión e informatización mundial promovida por la internacionalización de los medios de comunicación (Jameson, 2003: 325-326), será, entonces, un "Pensamiento Único", transformado en sentido común, que impedirá ver las consecuencias políticas, económicas y sociales que estaba produciendo este nuevo orden, al tiempo que promoverá nuevamente la apatía política y el conformismo (Borón, 1999).

Finalmente, debemos tener en cuenta la importancia ejercida por lo que podemos denominar la visión "mecanicista" de la globalización. Esta "ideología imposibilista" (Pucciarelli, 2002) entendía a la globalización como un fenómeno "natural" como es la lluvia, y creía, en ese sentido, que si nos atrevíamos a actuar de manera alternativa a sus dictados, sobrevendría una catástrofe económica y social de consecuencias "imprevisibles" (Coraggio, 1999; Aronskind, 2001). Así, se decía por entonces que cualquier política "populista" o "estatista", es decir, cualquier política alternativa que planteara cierta

\footnotetext{
${ }^{38}$ En particular se insistirá desde los centros de poder de Estados Unidos y los organismos multilaterales de crédito en la necesidad de constituir un tratado de libre comercio, denominado Asociación de Libre Comercio de las Américas (ALCA), que incluyera desde Tierra del Fuego, en el sur argentino, hasta Alaska. Este tipo de pacto llevaría, según decían, a la formación de una unidad americana conjunta que lograría trascender, al unificar, la conformación de los bloques regionales del Mercado Común del Sur (MERCOSUR) -constituido el 1 de enero de 1995 por Argentina, Brasil, Uruguay y Paraguay-, el Bloque andino -conformado por Ecuador, Venezuela y Colombia- y el tratado de Libre Comercio -constituido por México, Canadá y Estados Unidos en enero de 1994. Sobre las características y posibles efectos económicos de la firma del ALCA para la región latinoamericana, véase Arceo (2002). En cuanto al discurso a favor de la firma del Pacto, véase Fair (2007).

${ }^{39}$ Ello no implica que los conflictos no existieran. En efecto, como lo ha analizado Castells, durante la década del '90 existirá una importante resistencia "comunal" hacia los postulados de la globalización, especialmente por parte de los nacionalismos étnicos y culturales, como es el caso de la ex Yugoslavia, la ex Unión Soviética, Irlanda y España, y los fundamentalismos religiosos, como el fundamentalismo cristiano estadounidense, el talibán y las sectas japonesas (véase Castells, 2001). Sin embargo, lo que queremos destacar en este trabajo, más que la "realidad" o "falsedad" de los discursos, son sus "efectos de verdad", es decir, de qué modo este tipo de discursos logran generar nuevas realidades, muchas veces excluyendo o dejando fuera deliberadamente ciertas cuestiones o acontecimientos que podrían desbaratar sus teorías. Sobre este particular, véase White (1992).
} 
regulación al libre flujo del capital financiero, o bien pretendiera limitar de algún modo la expansión de la rentabilidad privada, sólo ocasionaría un malestar general en las "fuerzas del mercado" que fomentaría una salida masiva de las inversiones y el consiguiente "caos", ya sea hiperinflacionario o devaluatorio, con sus respectivas consecuencias políticas, económicas y sociales sobre el conjunto de la sociedad. De esta manera, con la excusa de promover la "seguridad jurídica" para el capital privado, se lograba fomentar una despolitización irracional de la sociedad, garantizando, al mismo tiempo, la libre rentabilidad del capital financiero internacional.

La llamada "Teoría de la Modernización reflexiva", sin embargo, afirma todo lo contrario. A continuación nos centraremos sobre esta cuestión.

\section{¿Modernidad reflexiva o modernidad irreflexiva?}

Según Scott Lash (1997b), existen tres etapas fundamentales en el desarrollo de la sociedad: la tradicional, la "modernidad simple" y la "modernidad compleja". La primera se basaba en lazos comunitarios entre los individuos, la segunda se apoyaba en lazos colectivos. En la época actual, en cambio, estaríamos asistiendo a una mayor liberación. En este sentido, mientras que en la modernidad simple existía un sometimiento de los sujetos, en la época actual estaríamos en presencia de una "modernidad reflexiva" que se caracterizaría por ser una sociedad con un creciente poder y autonomía de los actores sociales. Según este autor, este creciente poder de los sujetos se manifiesta en su liberación de estructuras sociales tales como los sindicatos, el Estado asistencial, las reglas laborales tayloristas y la burocracia gubernamental ${ }^{40}$ (Lash, 1997b: 141-142).

Ulrich Beck (1996), en la línea de Lash, también denomina a la época actual como "modernidad reflexiva". Según sostiene, durante la "modernidad simple" prevalecía un orden industrial que enjaulaba a los individuos con su extrema burocratización. Actualmente, en cambio, estaríamos en presencia de una "modernidad reflexiva" en donde los individuos se liberan de esa "jaula de hierro" weberiana. Además, en esta nueva época los fatalismos que caracterizaban a la modernidad simple se ven debilitados. En su lugar, se comienza a dar cuenta que las estructuras pueden ser transformadas por la acción humana.

Junto con los elementos positivos de la modernidad, prevalecen, sin embargo, elementos negativos, en lo que denomina la "globalización de los efectos colaterales". Beck hace hincapié, principalmente, en el riesgo que adquieren los problemas ecológicos y

\footnotetext{
40 Como señala Bourdieu, una de las mayores consecuencias que genera esta postura de defensa del individualismo extremo, es la destrucción del concepto de responsabilidad colectiva (en el accidente laboral, la enfermedad o la miseria). En su lugar, se lo reemplaza por una censura de la "víctima", única responsable de su desgracia (véase Bourdieu, 1999a: 19).
} 
militares. En este sentido, se refiere a que estamos asistiendo a una "sociedad de riesgo". No obstante, considera que en la época actual los sujetos se dan cuenta de que pueden intervenir sobre los efectos colaterales de la modernidad al tomar conciencia de que el daño depende enteramente de ellos en lugar de hacerlo de factores externos. ${ }^{41}$ Se produce, entonces, una "reinvención de lo político" (Beck, 1996).

Anthony Giddens (1995), finalmente, afirma que en la cultura tradicional y en la etapa industrial moderna, lo que para Beck y Lash constituye la "modernidad simple", los seres humanos estaban preocupados solamente por los riesgos de la naturaleza externa (malas cosechas, inundaciones, plagas o hambrunas). A partir de la globalización (es decir, en la época de "modernidad reflexiva"), en cambio, empezamos a preocuparnos menos sobre lo que la naturaleza puede hacernos y más sobre lo que hemos hecho a la naturaleza. Esto marcaría la transición desde una sociedad de "riesgo externo" a una de "riego manufacturado", es decir, una sociedad que quiere determinar su propio futuro en lugar de dejarlo a la tradición, la religión o los caprichos de la naturaleza. ${ }^{42}$ Coincidiendo nuevamente con el pensamiento de Beck y Lash, Giddens asegura que el fin de esta idea de naturaleza determinante implica que ahora hay pocos aspectos del medio ambiente material que nos rodea que no se hayan visto influidos de algún modo por la intervención humana, y que muchas cosas que antes eran naturales, ahora no lo son completamente (Giddens, 1995: 39-40).

\section{Las debilidades de la teoría}

Ahora bien, aunque es cierto que en los últimos años comenzó a crecer la idea de que se pueden hacer cosas para evitar las catástrofes ecológicas y naturales ${ }^{43}$ y se comenzó a analizar cómo prevenir esos riesgos y otros latentes, sostenemos, en contraposición a esta teoría, que, durante la fase crítica del sistema global neoliberal, es decir, durante la década del '90, el fenómeno de la globalización era entendido más como una vuelta a la visión de "riesgo externo", vinculado a ideas "fatalistas", que a la vigencia de un "riesgo

\footnotetext{
41 Mientras que la primera definición corresponde a lo que Luhmann denomina riesgo, la segunda corresponde a lo que entiende por peligro.

${ }^{42}$ A pesar de las semejanzas entre ambos, hay que remarcar que para Beck el riesgo es básicamente ambiental. Giddens, en cambio, se refiere a una inseguridad ontológica (psíquica y social). Por otro lado, cabe aclarar que mientras para Giddens la seguridad se logra a través de los "sistemas expertos", para el sociólogo alemán estos constituyen obstáculos y desconfía de ellos (véase Lash, 1997b).

${ }^{43}$ Un ejemplo es la crítica a la contaminación de las plantas de celulosa o "papeleras" uruguayas por parte de Argentina o la crítica del ex vicepresidente estadounidense Al Gore e importantes artistas internacionales a la contaminación de los países industrializados, lo que ha incluido recientemente la realización de recitales mundiales a beneficio en las que han participado varias estrellas reconocidas del ámbito artístico (Bono, Susan Sarandon, Sean Penn, Shakira, Juanes).
} 
manufacturado". Para entender nuestro argumento, creemos que resulta interesante analizar la perspectiva de Cornelius Castoriadis que retoma Bauman.

Según Castoriadis, en la Grecia Antigua prevalecía una visión "autónoma”, en el sentido de que los seres humanos creaban las reglas de su propio comportamiento y establecían el espectro de alternativas que debían de sopesar para decidir sus decisiones (citado en Bauman, 2003: 88). En la era premoderna, en cambio, la estrategia autónoma fue transformada en una estrategia "heterónoma", en la que el hombre no podía hacer nada frente a su destino inexorable (Ibíd.: 42). Con el advenimiento de la modernidad, surgió una estrategia que combinaba la heteronomía con la autonomía. Al igual que su antecesora premoderna, al individuo solamente le quedaba aceptar el destino y vivir una vida cuyos rasgos esenciales estaban ya prefijados en una totalidad duradera. Pero este tipo de sociedad era, al mismo tiempo, autónoma, en tanto subrayaba el origen humano de las totalidades (Ibíd.: 43). De esta forma, le otorgaba también cierta importancia a la posibilidad de acción individual.

Partiendo de este enfoque, podemos decir, con Bauman (2003), que, si todas las sociedades son autónomas, lo que caracterizó a la nuestra durante la fase crítica del sistema global neoliberal era la ausencia de consciencia de esta autonomía. Una sociedad con conciencia de ser autónoma sólo sería aquella que diera cuenta que las instituciones son de origen humano y que, por lo tanto, pueden ser diferentes de lo que son (Ibíd.: 89-90). No obstante, consideramos que, si la gran novedad de las primeras fases de la modernidad era presentar al orden como una tarea que la acción humana debía impulsar, producto en parte de la creciente racionalización generada por el desarrollo de la ciencia (Harvey, 1998), en los últimos tiempos la construcción de un orden alternativo dejó de considerarse una tarea a realizar. Se asistirá, en cambio, al regreso a una visión "heterónoma" que considera al fenómeno de la globalización como un orden "natural", "mecánico", donde los hechos, representados por las "fuerzas" impersonales del mercado, se nos imponen de una manera inexorable (Coraggio, 1999). Esta sociedad heterónoma se niega a reconocer el origen humano de las leyes que ella misma insta a obedecer, constituyendo una sociedad que, por esta razón, se imagina "confirmada y guiada por una autoridad que ella no ha creado: una autoridad proveniente de una fuerza externa" (Bauman, 2003: 145). De esta manera, la "integración y reproducción del "orden global" toman cada vez más la apariencia de un proyecto espontáneo y autoimpulsado" (Ibíd.: 109).

Esta cuestión se ve agravada, además, al plantearse que la única respuesta posible ante la globalización es la "sumisión con la que los hombres aceptan resignados las catástrofes naturales" (Ibíd.: 221). Así, en los últimos años hemos escuchado hasta el hartazgo que este no es sólo el mejor de los mundos posibles, sino que es el único que hay, que no hay alternativas posibles. De ahí, la famosa frase de Francis Fukuyama de que hemos llegado al "Fin de la Historia". Esto significa que, como se han agotado las 
interpretaciones alternativas al modelo de "democracia liberal" tras el fracaso estrepitoso del comunismo y del keynesianismo, tanto en su versión socialdemócrata europea, como en su versión "nacional-popular" o "populista" de América Latina, ${ }^{44}$ se habría terminado con la lucha política-ideológica. En palabras de Castells: "las ideologías políticas que emanan de las instituciones y organizaciones industriales, del liberalismo democrático basado en el Estado-Nación al socialismo basado en el trabajo, se ven privados del significado real en el nuevo contexto social. Por lo tanto, pierden su atractivo y, para tratar de sobrevivir, se embarcan en una serie de adaptaciones interminables, corriendo detrás de la nueva sociedad enarbolando banderas polvorientas de guerras olvidadas" (Castells, 2001: 394).

La consecuencia de este tipo de "lógica binarizable" (Lebrun, 2003: 99), fomentada reiteradamente desde los centros hegemónicos de poder, será la vigencia de un "Pensamiento único", transformado en sentido común, que impedirá ver las consecuencias políticas, económicas y sociales que estaba produciendo este nuevo orden, al tiempo que promoverá la apatía política, la resignación y el conformismo general de la sociedad (Borón, 1999; Aronskind, 2001).

Vimos anteriormente que una de las características de la economía actual consiste en que los capitales circulan constantemente en busca de mayores ganancias económicas. Al hacerlo, pueden desestabilizar lo que podían parecer economías sólidas, como ocurrió en Asia (1997), y otras no tan sólidas, como las crisis en México (1994) y Brasil (1999). ${ }^{45} \mathrm{El}$ sentimiento de constante riesgo se debe a que, desde la década del '90, con la apertura financiera llevada a cabo como requerimiento internacional para recibir préstamos de los organismos multilaterales de crédito y favorecer el ingreso de inversiones externas, asistimos a una economía basada en la especulación, "un inmenso mercado de capitales que circula con divisas, títulos y bonos diversos, acciones y papeles de deuda, creando artilugios financieros que, a causa de su enorme diversidad, dificultan su control" (Minsburg, 1999: 28). Estos capitales, a diferencia de los que caracterizaban a etapas

\footnotetext{
${ }^{44}$ En efecto, el modelo keynesiano no se aplicó del mismo modo en cada uno de los países. Así, en Europa existieron diferentes tipos de modelos benefactores de acuerdo al grado de organización sindical y el poder empresarial, entre otras cuestiones (véanse Esping Anderson, 1993; Harvey, 1998). En el caso de América Latina también hubo diferentes tipos de modelos benefactores, lo que ha llevado a varios trabajos a definir al modelo de industrialización sustitutivo como "nacional popular" o de "inserción hacia adentro" (véanse Cardoso y Faletto, 1976; Lechner, 1977). Existen, a su vez, algunas diferencias entre cada etapa de desarrollo del modelo regulador, ya sea la etapa más mercado-internista, conocida como primera etapa de industrialización por sustitución de importaciones o "populista", o bien la etapa más vinculada con el ingreso de inversiones externas o "desarrollismo", que corresponde a la segunda etapa de industrialización por sustitución de importaciones (véanse Diamand, 1973; Ferrer, 2006).

${ }^{45}$ El diciembre de 1994 México se vio obligada a devaluar su moneda, en lo que se conocería como el "Efecto Tequila”. Unos años después, Brasil continuaría el mismo camino, a partir de la devaluación del Real.
} 
previas del desarrollo de la modernidad, anclados en los Estados nacionales (Giddens, 1993), son ahora sumamente volátiles y veloces para desplazarse de un mercado a otro, con el consiguiente trastorno que ocasionan en las economías de los diferentes países afectados (Harvey, 1998).

El punto es que esta característica que define a la nueva fase del orden mundial les servirá a los teóricos de la globalización neoliberal como un pretexto para afirmar que los Estados nacionales tenían que cumplir a rajatabla con las "reglas" de la globalización. ${ }^{46}$ En caso de que algún país se atreviera a ignorarlas o modificarlas, se arriesgaría a severos castigos y, en el mejor de los casos, a una ausencia total de efectividad (Bauman, 2003: 200). En este sentido, se aducía que toda acción que se propusiera imponer un orden diferente al existente, sólo entorpecía el accionar, fluido y sabio, de la "mano invisible" ${ }^{47}$ y debía ser considerado una tarea peligrosa, condenada a arruinar y desarticular mucho más que a reparar o mejorar (Ibíd.: 109). De esta manera, se reforzaba la idea de que nada podía hacerse para cambiar el estado de cosas y que, si se intentase cambiarlas, las consecuencias serían catastróficas ${ }^{48}$ (Ibíd.: 145). Como señala Bauman, esta estrategia de apelación al "caos" resultaba muy efectiva, ya que las personas que se sienten inseguras sobre lo que puede deparar el futuro, no son verdaderamente libres para enfrentar los riesgos que exige una acción colectiva (Ibíd.: 183).

Así, durante la década del noventa se transformó en una realidad evidente de sentido común la creencia de que los individuos y los Estados eran impotentes frente a un poder que tomaba las decisiones fuera del ámbito de su control. Se decía, por entonces, que los Estados eran incapaces de regular la velocidad de movimiento de los capitales y de evitar las trágicas consecuencias que generaba el orden global. Como lo ha resumido de manera envidiable el conocido sociólogo español Manuel Castells (2001), uno de los teóricos más funcionales al sistema de dominación: "El Estado es cada vez más impotente para controlar la política monetaria, decidir su presupuesto, organizar la producción y el comercio, recabar los impuestos sobre sociedades y cumplir sus compromisos para proporcionar prestaciones

\footnotetext{
${ }^{46}$ En palabras del financista húngaro George Soros, "no caben dudas que los mercados fuerzan a los gobiernos a adoptar medidas impopulares que, sin embargo, son indispensables. Decididamente, el verdadero sentido del Estado reposa hoy en los mercados" (citado en Borón, 2000: 114).

${ }^{47}$ Recordemos que desde la teoría liberal inaugurada por Adam Smith en adelante se afirma que la "mano invisible" y "autorreguladora" del mercado permite el bienestar general de la sociedad a partir de la búsqueda de los intereses particulares. Sobre la falacia de su discurso, véase especialmente Gómez (2003).

${ }^{48}$ Esta imposición coactiva de "recetas" y la característica de "exterioridad" que presentan nos recuerda los dos componentes que Durkheim establece de los "hechos sociales". Según afirma, estos se caracterizan por ser formas de obrar y de pensar que se imponen al individuo de manera coactiva y externa (véase Durkheim, 1979: 37). Se trata, como pretendía este pensador, de entender a los "hechos sociales" como si fueran "cosas", es decir, objetivarlas o, en los términos del marxismo, "reificarlas" y, por lo tanto, naturalizarlas.
} 
sociales. En suma, ha perdido la mayor parte de su poder económico, si bien aún cuenta con cierta capacidad regulatoria y un control relativo sobre sus súbditos" (Castells, 2001: 282).

La consecuencia de esta visión neoliberal que define a los Estados-Nación como "obsoletos" e "impotentes" frente a la "red de poderes y contrapoderes" (Ibíd.: 298 y 335), y entiende a las políticas proteccionistas del mercado interno como "retórica nacionalista" (Ibíd.: 395), sólo puede ser un incremento aún mayor de la apatía, la resignación y el desinterés hacia todo aquello que sea político, "naturalizando" la supuesta inexorabilidad y ausencia de alternativas al fenómeno (Borón, 1999).

Como podemos observar, la visión actual que tenemos sobre la globalización nos lleva a creer que es poco lo que pueden hacer, tanto los ciudadanos como los Estados nacionales, para cambiar el curso de los asuntos mundiales o la manera en que son manejados. Más difícil se hace aún cuando la globalización es presentada por la visión neoliberal como la vigencia de un orden económico global en donde parecerían no existir "estructuras, clases, intereses económico-corporativos ni asimetrías de poder que cristalicen en relaciones de dependencia entre las naciones" (Borón, 1999: 221). Esto lleva a Bauman a afirmar que la tendencia más marcada de nuestra época es la separación del poder y la política $^{49}$ (Bauman, 2003: 82-83).

Sin embargo, son las mismas "reglas" que estos sectores imponen para estar "integrados al mundo" las que destruyen las culturas locales, amplían las desigualdades mundiales y empeoran la situación de los marginados. Se crea, entonces, un mundo de "ganadores y perdedores", donde unos pocos acrecientan su riqueza cada día más, al tiempo que muchos otros se ven condenados a la pobreza y a la desesperación ${ }^{50}$ (Giddens, 2000: 28). En este sentido, podemos decir que la "integración" que tanto pregonan es, en realidad, una "unidad paradójica, la unidad de la desunión" (Berman, 1988: 1), y esto es especialmente válido para los países menos desarrollados ${ }^{51}$ (Sader, 2001). En efecto, lejos

\footnotetext{
${ }^{49}$ En esta línea, por ejemplo, Castells (2001) señala que "El poder (...) ya no se concentra en las instituciones (el Estado), las organizaciones (empresas capitalistas) o los controladores simbólicos (empresas mediáticas, Iglesias). Se difunde en redes globales de riqueza, poder, información e imágenes que circulan y se transmutan en un sistema de geometría variable y geografía desmaterializada (...) En la era de la información, el poder es al mismo tiempo identificable y difuso. Sabemos lo que es, pero no podemos hacernos con él porque es una función de una batalla interminable en torno a los códigos culturales de la sociedad" (op. cit., p. 399).

50 Según el informe anual del 2004 del Programa de Naciones Unidas para el Desarrollo (PNUD), 500 personas en el mundo combinan un ingreso superior al de los 460 millones de habitantes del planeta (Clarín, 15/09/05). A su vez, un estudio del Banco Mundial señala que, en América Latina, una de cada cuatro personas, esto es, 135 millones de personas, vive (o sería mejor decir que sobrevive) con 2 dólares al día (Clarín, 15/02/06).

${ }^{51}$ Téngase en cuenta, en este sentido, que en momentos en los que se subraya la importancia de Internet como una fuente de interconexión de acceso mundial, en América Latina y el Caribe la cantidad de usuarios representan sólo el 3,2\% del total (Clarín, 11/07/07).
} 
de aplicarse en los países "centrales" las recetas de privatización, apertura comercial y financiera, desregulación y reducción del gasto público que son pregonados con énfasis en los países de la "periferia", allí se regula la economía a través de un Estado que interviene fuertemente en el mercado. ${ }^{52}$ En ese contexto es el que deben entenderse las políticas de proteccionismo estatal para las industrias nacionales y los subsidios a los agricultores europeos y estadounidenses que fueron moneda corriente durante la década del '90, al tiempo que se insistía desde los organismos multilaterales de crédito, la Organización Mundial del Comercio (OMC) y el Foro Económico Mundial sobre la importancia de "abrir los mercados" para alcanzar el bienestar mundial. En ese contexto, podemos afirmar, entonces, con Borón, que el término globalización está constituido por una acumulación de "simples ideologemas, racionalizaciones tendientes a ocultar, detrás de la supuesta inexorabilidad del "sentido común neoliberal", una opción política-económica muy clara a favor de los sectores más concentrados del capital" (Borón, 1999: 237). Estos sectores, constituidos por un pequeño número de grandes empresas y grandes países se ven enriquecidos en desmedro de una pauperización creciente de la mayoría de los países y la inmensa mayoría de las personas (Minsburg, 1999; Grueso, 2007). De este modo, las formas de dependencia que denunciaran en su momento los intelectuales latinoamericanos de la década del '60 y '70, adquiere nuevos ribetes que no eliminan las causas de su permanencia, perpetuando las restricciones el desarrollo regional.

\section{A modo de conclusión}

A lo largo de este trabajo nos propusimos abordar las profundas transformaciones estructurales provocadas por lo que hemos denominado el sistema global neoliberal. En ese contexto, pudimos observar la profunda transformación acontecida en el modelo de acumulación industrialista vigente desde la posguerra, que sería reemplazado por un nuevo régimen de acumulación con eje en el sector financiero; un modelo que, defendido por las principales fuerzas de poder económico y político, tuvo algunos grandes ganadores, los sectores más concentrados y centralizados del capital, y muchos grandes perdedores, los sectores populares y trabajadores en general, especialmente de los países "en vías de desarrollo". Este modelo hegemónico, que alcanzaría su fase de expansión crítica en la década del '90, con la profundización de las políticas neoliberales, no sólo tenía un gran poderío político y económico que lo respaldaba, sino también un discurso ideológico fuertemente atrayente y hegemonizante. Así, afirmaba que, tras el fracaso del comunismo y del Estado Benefactor, no había alternativas posibles al nuevo orden vigente, que se asistía

\footnotetext{
52 Así, entre 1980 y 1996 los planes de reforma y ajuste fiscal no impidieron que el gasto público de las 14 naciones más avanzadas de la Unión Europea se elevara del 43,3\% del PBI al 47,1\%, llegando a 55\% en casos como Suecia. En los países de América Latina, en cambio, el gasto público ronda el 23\% promedio, llegando a un mínimo de 11,8\% en Guatemala (citado en Borón, 2000, pp. 124 y 127).
} 
a un nuevo mundo en el que los antagonismos constitutivos eran eliminados en pos de una sociedad planetaria o una aldea global y en donde se creía que nada podía hacerse frente a las inexorables "fuerzas del mercado" que guiaban impersonalmente su proceder. En ese contexto, favorecido además por el poder de los grandes medios de comunicación masivos y sus intelectuales orgánicos, el modelo de globalización neoliberal logró expandirse fuertemente a escala mundial, despolitizando en gran medida a la sociedad, al tiempo que hacía lo propio con su discurso.

Podemos decir, entonces, que más que el fin de las "ideologías del fatalismo" y la consecuente "reinvención de lo político" (Beck, 1996) o la existencia de un "riesgo manufacturado" (Giddens, 1995), como plantean las teorías dominantes en el campo de la sociología, durante la década del '90 predominó una "Modernización irreflexiva", basada en ideas mecanicistas y deterministas que negaban, de esta manera, la contingencia inherente a todo orden político. Si bien esta teoría suele enfatizar la importancia de la acción, suele afirmar, también, que estamos en presencia de un mundo que está "más allá de la izquierda y la derecha" (Giddens, 1996) y en donde la autonomización del Estado Benefactor genera un "proceso de individuación" (Beck, 1996). De este modo, y en consonancia con la visión de la globalización como una "aldea global", esta teoría considera que las cuestiones de los derechos sociales son reemplazadas por cuestiones "predominantemente culturales" (Lash, 1997b: 165). No obstante, como señala Laclau, todo orden social está signado por un antagonismo que le es inherente y resulta inerradicable (Laclau y Mouffe, 1987; Laclau, 1996). En este sentido, podemos concluir que con la excusa de una "liberación" de las estructuras autoritarias y burocratizantes del modelo industrialista, la teoría de la Modernización Reflexiva termina defendiendo un esquema individualista, en el que los antagonismos constitutivos, es decir, lo propiamente político, son reducidos a la "pura administración" de cuestiones culturales (Mouffe, 1999, 2005; Laclau, 2003: 305, 2005b: 37). De esta manera, termina legitimando la propia despolitización social y con ella, la permanencia de la dominación sistémica.

\section{Post scriptum}

En los últimos años, la aplicación de las políticas neoliberales a escala global ha provocado nefastas consecuencias económicas y sociales. Incrementos descomunales de la deuda externa para respaldar fugas de capitales de los sectores privados más concentrados, un inédito proceso de apertura comercial y financiera que destruyó el aparato productivo vigente desde la posguerra y un conjunto de políticas de privatización de empresas públicas, flexibilización laboral y desregulación de los mercados han generado, especialmente en América Latina, la región más castigada, niveles de desempleo y subempleo históricos, una pobreza alarmante, una desigualdad de riquezas inédita y una precarización social vergonzantes. En ese contexto, en los últimos años han surgido liderazgos como los de Hugo Chávez en Venezuela, Evo Morales en Bolivia y Rafael 
Correa en Ecuador, pero también otros más moderados como Michelle Bachelet en Chile, Néstor Kichner en Argentina y "Lula" Da Silva en Brasil, que han comenzado a criticar muchas de las principales ideas del modelo hegemónico de globalización neoliberal. En particular, estos líderes regionales han desacreditado la idea de una globalización determinista que estaría gobernada por las "inescrutables e invencibles fuerzas de la naturaleza", para revalorizar la contingencia y la posibilidad de acción inherente a la política. Esta actual revalorización de la capacidad de "poder actuar", de "iniciar un nuevo comienzo", según decía Arendt (1996), es muy relevante, ya que nos permite ir dejando de lado, ahora sí, la visión naturalista o heterónoma de los fenómenos, que entendía a la política como subordinada al disciplinamiento impuesto por la economía, en pos de una visión constructivista que recupere su capacidad transformadora.

En este contexto, más aún a partir de la reciente crisis financiera de los Estados Unidos, que puso en evidencia la falacia del libre mercado a partir de un Estado que intervino fuertemente sobre la economía para hacerse cargo de las deudas del sector privado, ${ }^{53}$ todo indicaría que podemos ser optimistas y concluir que la fase crítica del sistema global neoliberal ha llegado a su fin. Sin embargo, debemos ser muy cautelosos ya que, si bien se está revalorizando la acción política, entendida como la capacidad de modificar el estado de cosas vigente, muchos de los postulados de la globalización neoliberal, como la necesidad de reducir el gasto público social para disminuir el déficit fiscal e impedir que se propague la inflación, ${ }^{54}$ o la idea de que el mercado es el ámbito eficiente por excelencia y la culpa de todo la tiene la burocracia, la ineficiencia y la corrupción del Estado, siguen siendo defendidos por algunos de los líderes latinoamericanos que han emergido. Por otra parte, continúan existiendo en estos países altos niveles de desempleo, pobreza y desigualdad, además de una redistribución fuertemente regresiva de la riqueza ${ }^{55}$. En cuanto a la sociedad civil, pese al incremento de

\footnotetext{
${ }^{53}$ En efecto, pese a su discurso basado en las bondades del libre mercado, el gobierno de Estados Unidos ha intervenido recientemente en la economía para evitar la quiebra del sector hipotecario nacional. En ese contexto, el presidente George W. Bush anunció un plan de salvataje multimillonario de los principales bancos hipotecarios involucrados (Fannie Mae y Freddie Mac) y una propuesta que contempla garantías estatales de 300 millones de dólares para créditos inmobiliarios, además de realizar una drástica reducción de las tasas de interés para promover la reanimación de la economía (Clarín, 24/01/08 y 27/07/08). Dejando de lado la retórica neoliberal, el presidente de la Reserva Federal, Ben Bernanke, solicitó recientemente, en la misma línea, la "vigilancia consolidada" de las instituciones financieras, autorizando a un regulador no especificado a establecer estándares de liquidez, disponibilidad de capitales y gestión de riesgo de los bancos de inversión" (Clarín, 11/07/08).

${ }^{54}$ Así, un estudio del Banco Mundial señala que, en toda América Latina, el gasto en infraestructura promedia el 2\% del PBI regional. Estas cifras contrastan con el 3,7\% que se invertía entre 1980 y 1985 (Clarín, 23/01/07).

${ }^{55}$ Un estudio reciente señala que en América Latina, pese a que se producen alimentos para tres veces su población total, el 38,5\% de aquel total, es decir, 205 millones de personas, son pobres, mientras que un $16 \%$ de los niños tiene desnutrición crónica. A su vez, en esta región el $10 \%$ más rico posee el $48 \%$ del total del ingreso, mientras que el 10\% más pobre sólo tiene el 1,6\% (Clarín, 08/11/07). En ese contexto, la mitad de la riqueza se concentra en sólo el 10\% de la población (Clarín, 16/05/08). 
las protestas, sigue vigente en ciertos sectores la creencia de una globalización en la que lo específicamente político, asociado al antagonismo, se encuentra ausente. Por otra parte, se hace difícil organizar la acción colectiva cuando presenciamos altos niveles de atomización social y cuando el consumismo fomenta aún más el individualismo.

En suma, podemos decir que hay algunas razones para ser optimistas. En particular, resulta promisoria la reciente creación de un bloque de centro-izquierda liderado por Hugo Chávez y Evo Morales que plantea de manera enfática la posibilidad de dar voz a los sectores más desposeídos de la sociedad. Sin embargo, hay también muchas razones para ser cautelosos. Una de las principales es precisamente la fuerte despolitización social, resignación, o bien consenso pasivo, que continúa presente en gran parte de los sectores populares. Ello se debe en gran medida a la fragmentación heredada tras décadas de políticas neoliberales y al estrepitoso fracaso de los socialismos "realmente existentes", pero también se debe a la imposibilidad de construir nuevas hegemonías que logren trascender la fuerte dispersión social existente. En épocas en las que la globalización postliberal continúa con su doble discurso, como se hace evidente en el hecho de que los países centrales insisten sobre la necesidad de liberar el comercio mundial y los flujos financieros, al tiempo que continúan protegiendo religiosamente a sus propias industrias nacionales y subsidiando a sus agricultores, además de endurecer las leyes sobre la inmigración, mientras se refieren a la importancia de expandir los demás tipos de libertades; ${ }^{.6}$ y en tiempos también en los que se continúa por otros medios el discurso excluyente y antipopular del capitalismo, reconfigurando la alteridad desde el otrora enemigo "comunista" de la Guerra Fría, al actual "terrorista"57 y "populista", lo que se observa en la descalificación que debe soportar todo aquel que pretenda plantear una alternativa diferente que ponga en peligro el discurso, y por lo tanto la rentabilidad, de los sectores más concentrados del capital, quizás sea un buen momento para dejar a un lado la vieja

\footnotetext{
${ }^{56}$ En efecto, pese al discurso sobre la "sociedad red" (Castells, 2001) y la interconexión mundial que se promueve desde los centros hegemónicos de poder y algunos círculos intelectuales, el gobierno de Francia ha expulsado, sólo entre enero y junio del 2008, a 14.660 inmigrantes indocumentados. El gobierno británico, por su parte, afirmó que denunciará en su sitio oficial de Internet a las empresas de ese país que contraten como trabajadores a inmigrantes indocumentados y señaló que ya ha impuesto fuertes multas a unas 200 empresas infractoras. Por último, el gobierno "socialista" de España ha aprobado recientemente una medida que establece que los inmigrantes indocumentados pueden ser arrestados por 18 meses antes de ser expulsados y repatriados a sus países de origen y analiza un plan para el retorno voluntario de un millón de inmigrantes para septiembre de 2009 (Clarín, 20/06/08).

${ }^{57}$ Este tipo de discurso se ha hecho presente, incluso, en el candidato demócrata a la presidencia de Estados Unidos, Barack Obama, quien recientemente declaró que "hay que derrotar al terrorismo como se derrotó al comunismo" (frase citada en Clarín, 25/07/08).
} 
dicotomía izquierdista entre reforma o revolución y articular un nuevo bloque de poder contrahegemónico que, como suele ser moneda corriente en los sectores dominantes, trascienda las diferencias circunstanciales y sectarias en pos de un proyecto político común. Sólo de esta manera la esperanza que parece renacer podrá constituirse en una nueva realidad alternativa. 


\section{Bibliografía}

Anderson, P. (1997), "Neoliberalismo: balance provisorio", en Sader, Emir y Gentilli, Pablo (comps.), La trama del neoliberalismo. Mercado, crisis y exclusión social, Oficina de publicaciones del CBC, Universidad de Buenos Aires, Bs. As.

Arceo, E. (2002) ALCA: Neoliberalismo y nuevo pacto colonial, CTA, Bs. As. Arendt, H. (1996), La condición humana, Paidós, Barcelona.

Aronskind, R. (2001), "Globalización en Argentina, o la voluntad soberana de subdesarrollarse", Época, Vol. 3, N³, pp. 219-244.

Assoun, P. (1984), Freud y Nietszche, FCE, México.

Basualdo, E. (2006): Estudios de historia económica argentina. Desde mediados del siglo XX a la actualidad, Siglo XXI-FLACSO, Bs. As.

Bauman, Z. (2003), En busca de la política, FCE, Bs. As.

Beck, U. (1996), 'Teoría de la Modernización Reflexiva', en Beriain, Josexco (comp.), Las Consecuencias Perversas de la Modernidad, Anthropos, Barcelona.

Berman, M. (1988), Todo lo sólido se desvanece en el aire, Siglo XXI, Madrid.

Borón, A. (1999), "Pensamiento único" y resignación política: los límites de una falsa coartada", en Borón, Atilio, Gambina, Julio y Minsburg, Naum (comps.), Tiempos violentos. Neoliberalismo, globalización y desigualdad en América Latina, CLACSO, Bs. As.

Idem (2000), "Los nuevos leviatanes y la polis democrática", en Tras el búho de Minerva. Mercado contra democracia en el capitalismo de fin de siglo, FCE, Bs. As., pp. 103-132.

Bourdieu, P. (1984), Sociología y cultura, Grijalbo, México DF.

Idem (1991), "Estructuras, hábitus, prácticas", en El sentido práctico, Taurus, Madrid.

Idem (1999a), Contrafuegos. Reflexiones para servir a la resistencia contra la invasión neoliberal, Anagrama, Barcelona.

Idem (1999b), La distinción. Criterio y bases sociales del gusto, Taurus, Madrid. 
Idem (2000a), "Algunas propiedades de los Campos", en Cuestiones de Sociología, Istmo, Madrid.

Idem (2000b), 'Las formas del capital. Capital económico, capital cultural y capital social', en Poder, Derecho y Clases Sociales, Desclée de Brower, Bilbao.

Canelo, P. (2004), "La política contra la economía: Los elencos militares frente al programa económico de Martínez de Hoz", en Pucciarelli, Alfredo (coord), Militares, Tecnócratas y políticos, Siglo XXI, Bs. As., pp. 219-312.

Cardoso, F. y Faletto, E. (1976), Desarrollo y dependencia en América Latina, Siglo XXI, Bs. As.

Castellani, A. (2002), "Implementación del modelo neoliberal y restricciones al desarrollo en la Argentina contemporánea”, en AA.VV., Más allá del pensamiento único, CLACSO, Bs. As., pp. 81-142.

Idem (2004), "Gestión económica liberal corporativa y transformaciones en el interior de los grandes agentes económicos de la Argentina durante la última dictadura militar", en Pucciarelli, Alfredo (coord), Militares, Tecnócratas y políticos, Siglo XXI, Bs. As., pp. 173-218.

Castells, M. (2001), La era de la información, Vol. II, Siglo XXI, Bs. As.

Cavarozzi, M. (1997), Autoritarismo y democracia (1955-1996). La transición del Estado al mercado en la Argentina, Ariel, Bs. As.

Cheresky, I. (2006), "La ciudadanía y la democracia inmediata", en Cheresky, Isidoro (comp.), Ciudadanía, sociedad civil y participación política, Miño y Dávila, Bs. As.

Coraggio, J. L. (1999), “¿Es posible pensar alternativas a la política social neoliberal?", en Nueva Sociedad, N¹64, pp. 99-105.

De Santos, B. (2006): La fidelidad del olvido, El cielo por asalto, Bs. As.

Diamand, M. (1973), Doctrinas económicas, desarrollo e independencia, Paidós, Bs. As.

Dornbusch, R. y Edwards, S. (1990), Macroeconomía del populismo en América Latina, FCE, México.

Durkheim, E. (1979), Las reglas del método sociológico, La pléyade, Bs. As.

Esping Andersen, G. (1993), Los tres mundos del Estado de Bienestar, Alfons el Magnanim, Valencia, España.

Ezcurra, A. M. (1998), ¿Qué es el neoliberalismo? Evolución y límites de un modelo excluyente, Ideas, Bs. As. 
Fair, H. (2007), "Identidades y representación. El rol del Plan de Convertibilidad en la consolidación de la hegemonía menemista (1991-1995)", Tesis de Maestría para aplicar al grado de Magíster en Ciencias Sociales, Facultad Latinoamericana de Ciencias Sociales (FLACSO), Sede Argentina, mimeo, Bs. As.

Idem (2008a), "Los piqueteros como síntoma espectral emergente del orden policial menemista", en e-l@tina. Revista electrónica de estudios latinoamericanos, Vol. 6, $\mathrm{N}^{\circ} 22$, Bs. As., pp. 13-29. Disponible en línea en http://www.iigg.fsoc.uba.ar/hemeroteca/elatina/elatina22.pdf

Idem (2008b), "El rol de los componentes pasivos en la legitimación del discurso menemista", en Revista Electrónica de Psicología Política, Vol. 6, №16, San Luis. Disponible en línea en http://www.psicopol.unsl.edu.ar/marzo08_03.pdf

Idem (2008c), "La globalización neoliberal. Transformaciones y efectos de un discurso hegemónico", en Kairós, Vol. 12, N²1, Universidad Nacional de San Luis (UNSL). Disponible en línea en http://www.revistakairos.org/k21-archivos/Fair.pdf

Ferrer, A. (2006), La economía argentina, Bs. As., FCE.

Forte, M. A. (2003), "Globalización: un clásico de la modernidad", en Reigadas, Marcela y Cullen, Carlos (comps.), Globalización y nuevas ciudadanías, Suárez, Bs. As.

Ffrench Davis, R. (2004), Entre el neoliberalismo y el crecimiento con equidad. Tres décadas de política económica en Chile, Siglo XXI, Bs. As.

Gambina, J. (1999), "La crisis y su impacto en el empleo", en Borón, Atilio, Gambina, Julio y Minsburg, Naum (comps.), Tiempos violentos. Neoliberalismo, globalización y desigualdad en América Latina, CLACSO, Bs. As.

García Delgado, D. (1994), El cambio de relaciones Estado-sociedad en el proceso de modernización en Argentina, mimeo, Instituto de investigaciones de la Facultad de Ciencias Sociales, UBA, Bs. As.

Idem (1998), Estado Nación y globalización, s/d, Bs. As.

Giddens, A. (1987), Las nuevas reglas del método sociológico, Amorrortu, Bs. As.

Idem (1993), Consecuencias de la modernidad, Alianza, Madrid.

Idem (1995), La constitución de la sociedad, Amorrortu, Bs. As.

Idem (1996), Mas allá de la izquierda y la derecha, Cátedra, Madrid. 
Idem (2000): Un mundo desbocado. Los efectos de la globalización en nuestras vidas, Taurus, Madrid.

Gómez, R. (2003), Neoliberalismo globalizado. Refutación y debacle, Macchi, Bs. As.

Grueso, D. (2007), "La globalización y la justicia. Hacia las identidades culturales", en Hoyos Vazquez, Guillermo, Filosofía y teorías políticas entre la crítica y la utopía, CLACSO, Bs. As., pp. 127-142.

Habermas, J. (1989), 'El Contenido Normativo de la Modernidad', en El Discurso Filosófico de la Modernidad, Taurus, Madrid.

Idem (1990), Pensamiento Post-Metafísico, Taurus, México.

Idem (1995), Problemas de legitimación en el capitalismo tardio, Amorrortu, Bs. As.

Harvey, D. (1998), La condición de la posmodernidad, Amorrortu, Bs. As.

Jameson, F. (2003), "La posmodernidad y el mercado", en Zizek, Slavoj (comp.), Ideología. Un mapa de la cuestión, FCE, Bs. As., pp. 309-328.

Laclau, E. y Mouffe, C. (1987), Hegemonía y estrategia socialista, FCE, Bs. As.

Laclau, E. (1996), Emancipación y diferencia, Ariel., Bs. As.

Idem (2003), "Identidad y hegemonía: el rol de la universalidad en la constitución de lógicas políticas", en Butler, Judith, Laclau, Ernesto y Zizek, Slavoj, Contingencia, hegemonía y universalidad. Diálogos contemporáneos en la izquierda, FCE, Bs. As.

Idem (2005a), La Razón populista, FCE, Bs. As.

Idem (2005b), “Populismo: ¿qué hay en el nombre?”, en Arfuch, Leonor (comp.), Pensar este tiempo. Espacios, afectos, pertenencias, Paidós, Bs. As.

Lash, S. (1997a), Sociología del posmodernismo, Amorrortu, Bs. As.

Idem (1997b), 'La Reflexividad y sus Dobles: estructura, estética, comunidad', en Beck, Ulrich, Giddens, Anthony y Lash, Scott, Modernización Reflexiva, Alianza, Madrid.

Lebrun, J. P. (2003), Un mundo sin límite. Ensayo para una clínica psicoanalítica de lo social, del Serbal, Barcelona.

Lechner, N. (1977), La crisis del Estado en América Latina, El Cid, Caracas. 
Lipovetsky, G. (2000), "Espacio público y espacio privado en la era posmoderna", en Arditi, Benjamín (ed.), El reverso de la diferencia. Identidad y política, Nueva Sociedad, Caracas.

Llach, J. (1997), Otro siglo, otra Argentina, Ariel, Bs. As.

Lyotard, J. F. (1992), La condición postmoderna, Amorrortu, Bs. As.

Luhmann, N. (1997), Observaciones de la modernidad. Racionalidad y contingencia en la sociedad moderna, Paidós Studio, Barcelona.

Markoff, J. y Montecinos, V. (1994), "El irresistible ascenso de los economistas", en Desarrollo Económico, Vol. 34, Nº133, Bs. As.

Marx, K. y Engels, F. (2001), Manifiesto del partido comunista, CS ediciones, Bs. As.

Minsburg, N. (1999), “Transnacionalización, crisis y papel del Fondo Monetario Internacional y del Banco Mundial", en Borón, Atilio, Gambina, Julio y Minsburg, Naum (comps.), Tiempos violentos. Neoliberalismo, globalización y desigualdad en América Latina, CLACSO, Bs. As.

Mouffe, C. (1999), El retorno de lo político. Comunidad, ciudadanía, pluralismo, democracia radical, Paidós, Bs. As.

Idem (2005), "Política y pasiones: las apuestas de la democracia", en Arfuch, Leonor (comp.), Pensar este tiempo. Espacios, afectos, pertenencias, Paidós, Bs. As.

Murillo, M. V. (2005), Sindicalismo, coaliciones partidarias y reformas de mercado en América Latina, Siglo XXI, Bs. As.

Pucciarelli, A. (2002), La democracia que tenemos. Declinación económica, decadencia social y degradación política en la Argentina actual, Libros del Rojas, Bs. As.

Quiroga, H. (2006), "Déficit de ciudadanía y transformaciones del espacio público", en Cheresky, Isidoro (comp.) Ciudadanía, sociedad civil y participación política, Miño y Dávila, Bs. As.

Repetto, F. (1999), "Transformaciones de la política social y su relación con la legitimidad: notas sobre América Latina en los 90s”, en POSTData, N5.

Ritzer, G. (1996), La McDonalización de la sociedad: un análisis de la racionalización de la vida cotidiana, Ariel, Barcelona. 
Roberts, K. (2002), “El sistema de partidos y la transformación de la representación política en la era neoliberal latinoamericana", en Cavarozzi, Marcelo y Abal Medina, Juan Manuel (comps.), El asedio de la política. Los partidos latinoamericanos en la era neoliberal, Homo Sapiens, Bs. As.

Sader, E. (2001), El ajuste estructural en América Latina. Costos sociales y alternativas, CLACSO, Bs. As.

Svampa, M. (2005), La sociedad excluyente. La Argentina bajo el signo del neoliberalismo, Taurus, Bs. As.

Tenti Fanfani, E. (1993), "Cuestiones de exclusión social y política", en Minujin, Alberto (ed.), Desigualdad y exclusión: desafios para la política social de fin de siglo, UNICEF-Losada, Bs. As., pp. 241-274.

Torre, J. C. (1997), "Las dimensiones políticas e institucionales de las reformas estructurales en América Latina", en Revista de la CEPAL, No46, Santiago de Chile.

Idem (1998), El proceso político de las reformas económicas en América Latina, Paidós, Bs. As.

Verón, E. (1985), "El discurso tecnocrático”, fragmentos tomados de Le corps $d u$ president, (Traducción de la cátedra de "Cultura y lenguajes políticos", Ques-Sagol, Carrera de Ciencia Política, Facultad de Ciencias Sociales, Universidad de Buenos Aires), mimeo, Ivry sur, Seine.

Villarreal, J. M. (1996), La exclusión social, Norma-FLACSO, Bs. As.

Wallerstein, I. (1979), "El moderno sistema mundial”, en $O S A L, \mathrm{~N}^{\circ} 9$, Bs. As.

Weber, M. (1984), Economía y Sociedad. Esbozos de una sociología comprensiva, FCE, México DF.

White, H. (1992), El contenido de la forma. Paidós, Barcelona.

Fuentes

Diario Clarín (Argentina). 